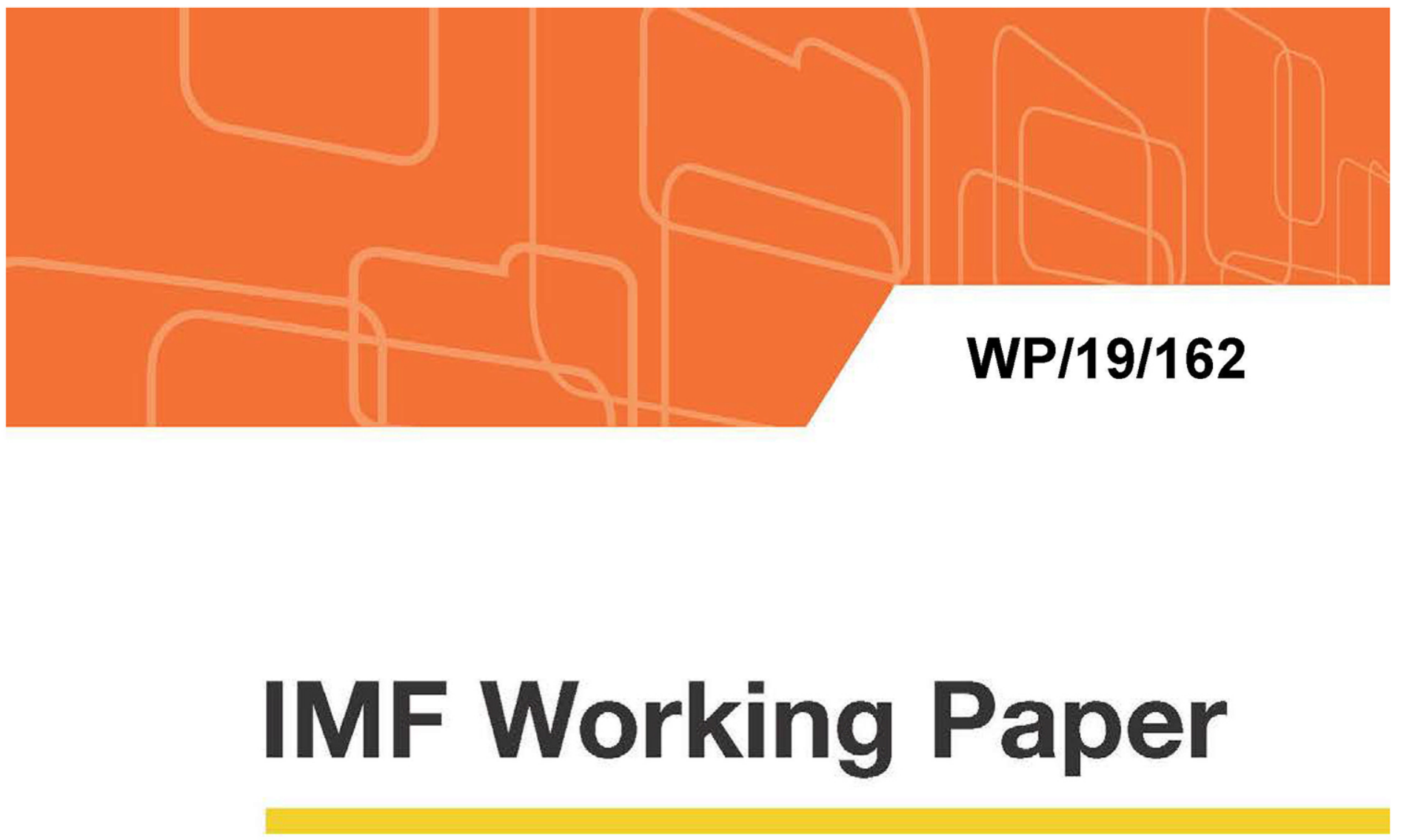

\title{
The Nonlinear Relationship Between Public Debt and Sovereign Credit Ratings
}

by Metodij Hadzi-Vaskov and Luca Antonio Ricci

IMF Working Papers describe research in progress by the author(s) and are published to elicit comments and to encourage debate. The views expressed in IMF Working Papers are those of the author(s) and do not necessarily represent the views of the IMF, its Executive Board, or IMF management.

$$
\text { I N T E R N A T I O N A L M O N E T A R Y F U N D }
$$




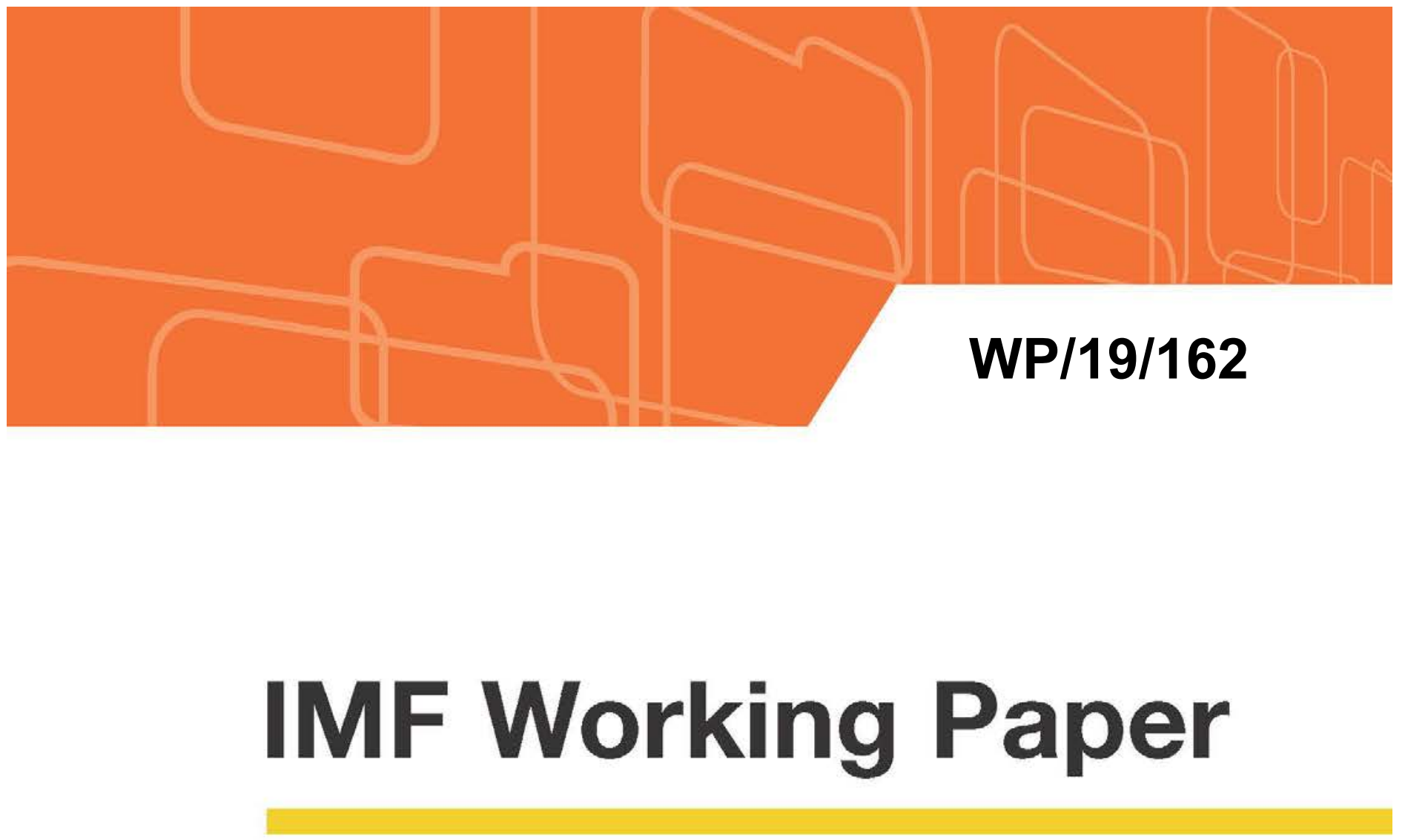

\section{The Nonlinear Relationship Between Public Debt and Sovereign Credit Ratings}

by Metodij Hadzi-Vaskov and Luca Antonio Ricci

IMF Working Papers describe research in progress by the author(s) and are published to elicit comments and to encourage debate. The views expressed in IMF Working Papers are those of the author(s) and do not necessarily represent the views of the IMF, its Executive Board, or IMF management.

$$
\text { I N T E R N A T I O N A L M O N E T A R Y F U N D }
$$




\title{
IMF Working Paper
}

Western Hemisphere Department

\section{The Nonlinear Relationship Between Public Debt and Sovereign Credit Ratings \\ Prepared by Metodij Hadzi-Vaskov and Luca Antonio Ricci}

Authorized for distribution by Luca Antonio Ricci

July 2019

IMF Working Papers describe research in progress by the author(s) and are published to elicit comments and to encourage debate. The views expressed in IMF Working Papers are those of the author(s) and do not necessarily represent the views of the IMF, its Executive Board, or IMF management.

\begin{abstract}
This study investigates the nonlinear relationship between public debt and sovereign credit ratings, using a wide sample of over one hundred advanced, emerging, and developing economies. It finds that: i) higher public debt lowers the probability of being placed in a higher rating category; ii) the negative debt-ratings relationship is nonlinear and depends on the rating grade itself; and iii) the identified nonlinearity explains the differential impact of debt on ratings in advanced economies versus in emerging markets and developing economies. These results hold for both gross debt and net debt, and are robust to alternative dependent variable definitions, analytical techniques, and empirical specifications. These findings underscore the potential for fiscal consolidation in helping countries achieve a better credit rating.
\end{abstract}

JEL Classification Numbers: E44; E62; G15; G24

Keywords: Credit ratings, Public debt, Credit rating agencies, Financial markets, Advanced economies, Emerging markets, Non-linearities

Author's E-Mail Address: mhadzivaskov@imf.org, 1ricci@imf.org 


\section{INTRODUCTION}

Higher levels of public debt generally increase fiscal vulnerabilities and raise concerns about the sovereign's capacity and ability to service debt obligations. As such, higher debt levels are expected to be associated with perceptions of lower creditworthiness, and result in weaker sovereign credit ratings. This relationship is illustrated in Figure 1 using credit ratings data from Fitch Ratings and government debt-to-GDP ratios over the period 1998-2014. As expected, countries with higher debt-to-GDP ratios also tend to have lower sovereign credit ratings. Figure 1 also shows some clear differences between Emerging Markets and Developing Economies (EMDEs) and Advanced Economies (AEs) — for the same level of debt AEs typically have higher credit ratings than EMDEs - as well as within each country grouping. Exceptions from this pattern are visible for example in a few AEs that enjoy very high credit ratings despite also having high debt levels (as they are considered safe heavens) as well as some developing economies with both low debt levels and low credit ratings (as they have limited access to market). This relationship holds both for gross debt (Panel A) and net debt (Panel B), defined as the difference between general government gross debt and financial assets corresponding to debt instruments. ${ }^{1}$

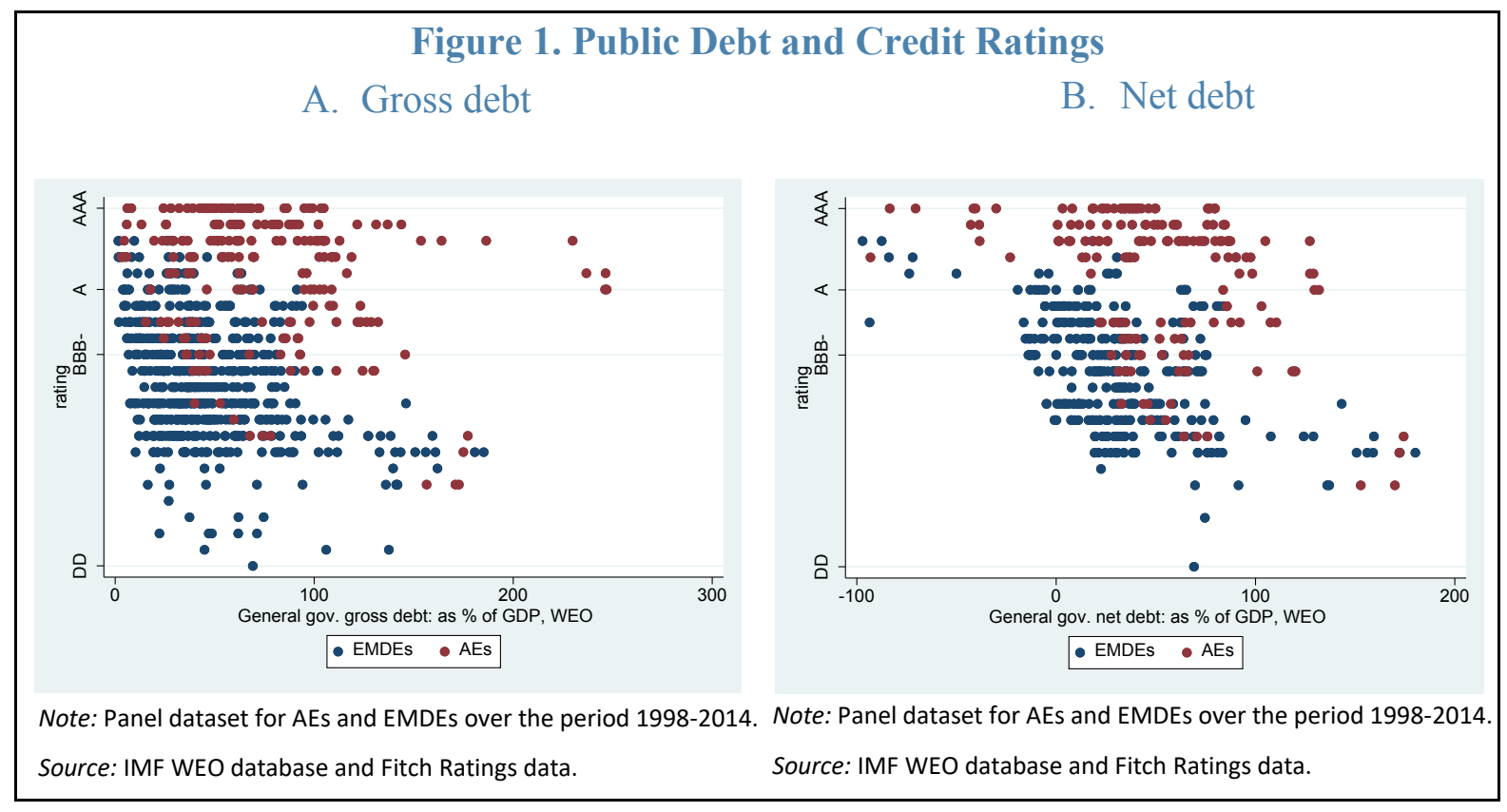

This paper formally investigates the empirical relation between public debt and sovereign credit ratings using alternative analytical methods. There are three main reasons for the focus on debt when assessing ratings. First, debt is generally found to be one of the most important

\footnotetext{
${ }^{1}$ See IMF (2014) for definitions of gross debt, net debt, and government financial assets. The distinction between gross and net debt is important as they may have different impact on economic and financial performance. For instance, see Hadzi-Vaskov and Ricci (forthcoming) for the impact of gross and net debt on sovereign bond spreads. As net debt lowers the sample, we will focus mainly on gross debt and use net debt as robustness.
} 
explanatory variables for credit ratings (e.g. see Afonso, Gomes, and Rother, 2011; Brůha et al., 2017). Second, the findings from a dominance analysis, which explores the relative importance of various explanatory variables, suggests that debt may be more important than other factors in explaining sovereign ratings. Third, among the important factors affecting sovereign credit ratings, public debt is a key one that policymakers can directly influence.

The paper offers a deeper analysis of the relation between debt and ratings: first, by uncovering the nonlinear nature of such relation; and second by showing how such nonlinearity is the main reason for the apparent difference between AE and EMDCs even when controlling for the income level. The analysis employs various empirical procedures, techniques, and country groupings. Section II provides a brief review of the literature. Section III describes the dataset and sets the empirical strategy. Section IV presents the main empirical results and Section V includes various robustness checks. Finally, Section VI offers some concluding remarks.

\section{Literature ReVIEW}

The determinants of sovereign credit ratings have been the topic of investigation in different empirical studies. In a pioneering study, Cantor and Packer (1996) identify a set of determinants of sovereign credit ratings and quantify their impact. In their analysis, which divided the rating scale into equally spaced intervals, they find that the following six factors seem to play a role in determining ratings: income per capita, GDP growth, inflation, external debt, level of economic development, and default history. Using linear, logistic, and exponential transformations of the rating scales, Afonso (2003) also finds evidence about the importance of those six variables for counties' credit ratings.

Afonso, Gomes, and Rother (2011) conclude that changes in GDP per capita, GDP growth, government debt, and the fiscal balance have a short-run impact, while government effectiveness, external debt, level of foreign reserves, and default history play a role as longterm determinants of credit ratings. Bissoondoyal-Bheenick (2005) suggests that the relevance of economic variables is not uniform across the different rating categories and country groups, as the importance assigned by credit rating agencies to different economic variables seems to depend on the level of economic development. In this context, a number of studies aim to reproduce sovereign ratings as a function of broad set of economic determinants (see Bissoondoyal-Bheenick, 2005; Mora, 2006; Afonso, Gomes, and Rother, 2011; Gaillard, 2014). Boumparis et al. (2015) show that Euro-zone countries undergoing a crisis faced a stronger rating penalty.

The approach in this analysis is related, though distinct from the set of empirical studies. First, this study focuses in particular on the impact of public debt-to-GDP ratio on sovereign credit ratings employing a wide range of analytical techniques, specifications, and country groupings. Second, it investigates the nonlinear nature of such relationship and how such nonlinearity relates to differences between advanced economies and emerging markets and developing economies. 


\section{DATASET AND EMPIRICAL Strategy}

\section{A. Dataset description}

Data on general government gross and net debt (as percent of GDP) comes from the IMF's World Economic Outlook (WEO) database. ${ }^{2}$ Data on sovereign credit ratings comes from Fitch Ratings, and relate to the last credit rating assigned during the year, which largely mitigates endogeneity concerns. As an alternative measure we also use the Institutional Investor Index, obtained from Institutional Investor, Inc; this indicator is based on information about the likelihood of default provided by senior economists and sovereign-risk analysts at leading global banks and money management as well as securities firms. Among the control variables used in the analysis, GDP and inflation come from the WEO database, PPP GDP per capita from the World Bank's World Development Indicators, while the 10year U.S. interest rates and the implied volatility index VIX are retrieved from Bloomberg. Series on sovereign bond spreads come from JP Morgan's Emerging Market Bond Index Global (EMBIG). The indicator for export diversification comes from Ding and HadziVaskov (2017).

The analysis covers annual data over the period 1998-2014 for 106 countries that belong to several country groups. Both advanced economies (AEs) and emerging and developing economies (EMDEs) are included in various specifications. Overall, the broadest set of countries included in this analysis comprises of 31 AEs and 75 EMDEs, of which 11 from Emerging Europe, 8 from the Commonwealth of Independent States (CIS), 9 from Emerging Asia, 17 from Latin America and the Caribbean (LAC), 9 from Middle-East and North Africa (MENA), and 21 from Sub-Saharan Africa (SSA).

\section{B. A glance at debt and rating data}

Before moving to the formal empirical tests, this section provides a description of some key data patterns. Figure 2 visualizes the relationship between gross debt and sovereign credit ratings for different country groups: AEs, EMDEs, and all regional groupings of EMDEs according to the IMF WEO. ${ }^{3}$ The negative relationship applies to all country groups and is very similar across regions of EMDEs. In addition, the slope for AEs is somewhat flatter, largely due to countries with both very high debt levels and credit ratings in the top notches (e.g. Japan). Within the EMDEs, the slope is negative for all region, with some differences (for example it is somewhat flatter for SSA), something we will come back to.

\footnotetext{
${ }^{2}$ Note that the Government Finance Statistics Manual 2014 definition generally covers more debt instruments than actually used in the WEO database.

${ }^{3}$ The relationship between debt and sovereign credit ratings for the country groupings looks very similar when debt is measured in net terms (available upon request).
} 


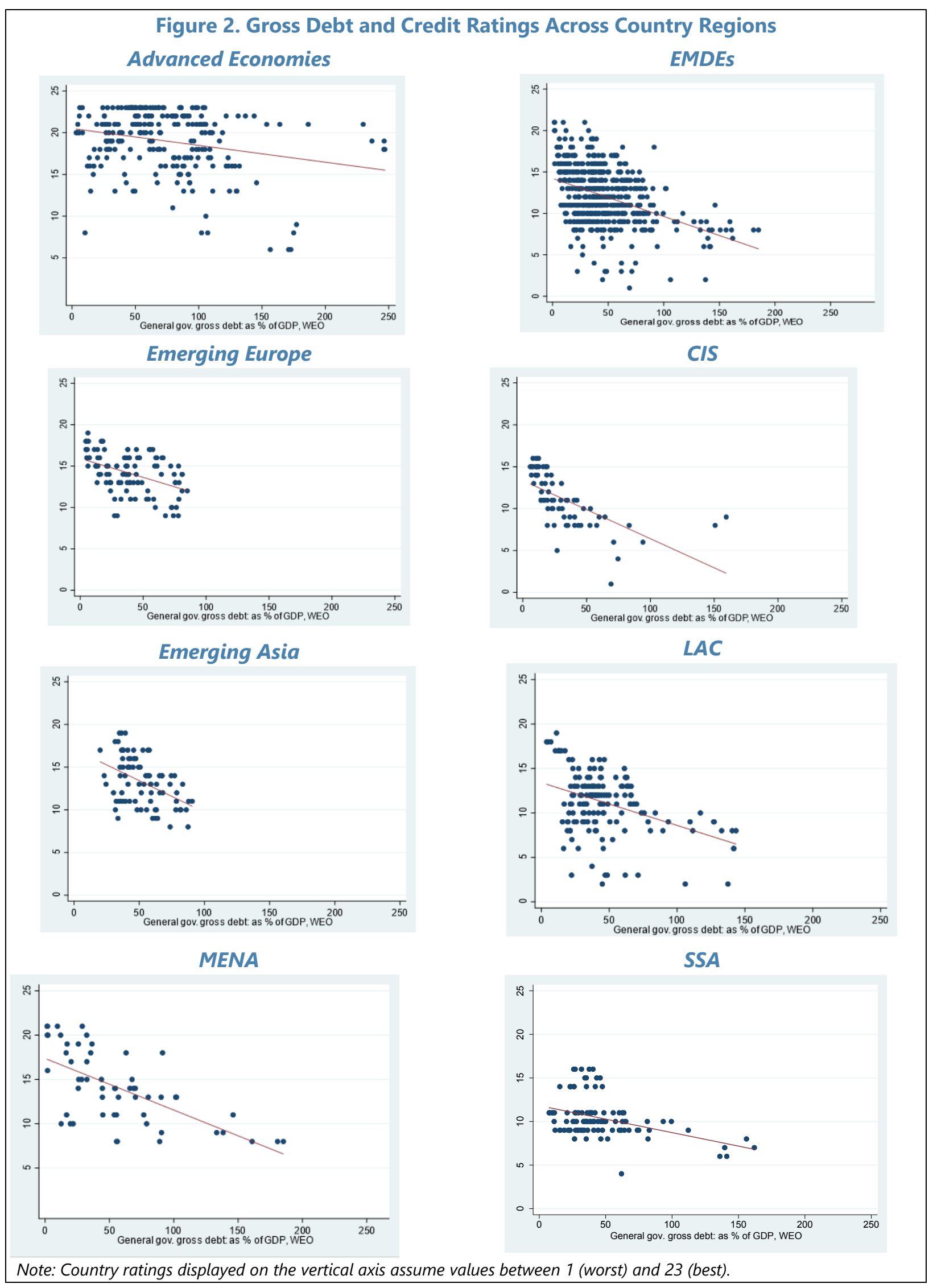

CInternational Monetary Fund. Not for Redistribution 
A key observation that comes to mind from such a figure, especially when comparing AEs and EMDEs, is that richer and more developed countries are likely to also have in place better institutional frameworks and enjoy perceptions of better creditworthiness. Figure 3 provides visual evidence in support of such conjectures, showing a positive relationship between countries' higher GDP per capita and their sovereign credit ratings. The relation was indeed highlighted in various studies such as Bissoondoyal-Bheenick (2005). As we will see, even controlling for GDP per capita, some differences in AE and EMDC will persist, and we will show that such remaining difference is related to the nonlinear nature of the relation between debt and rating.

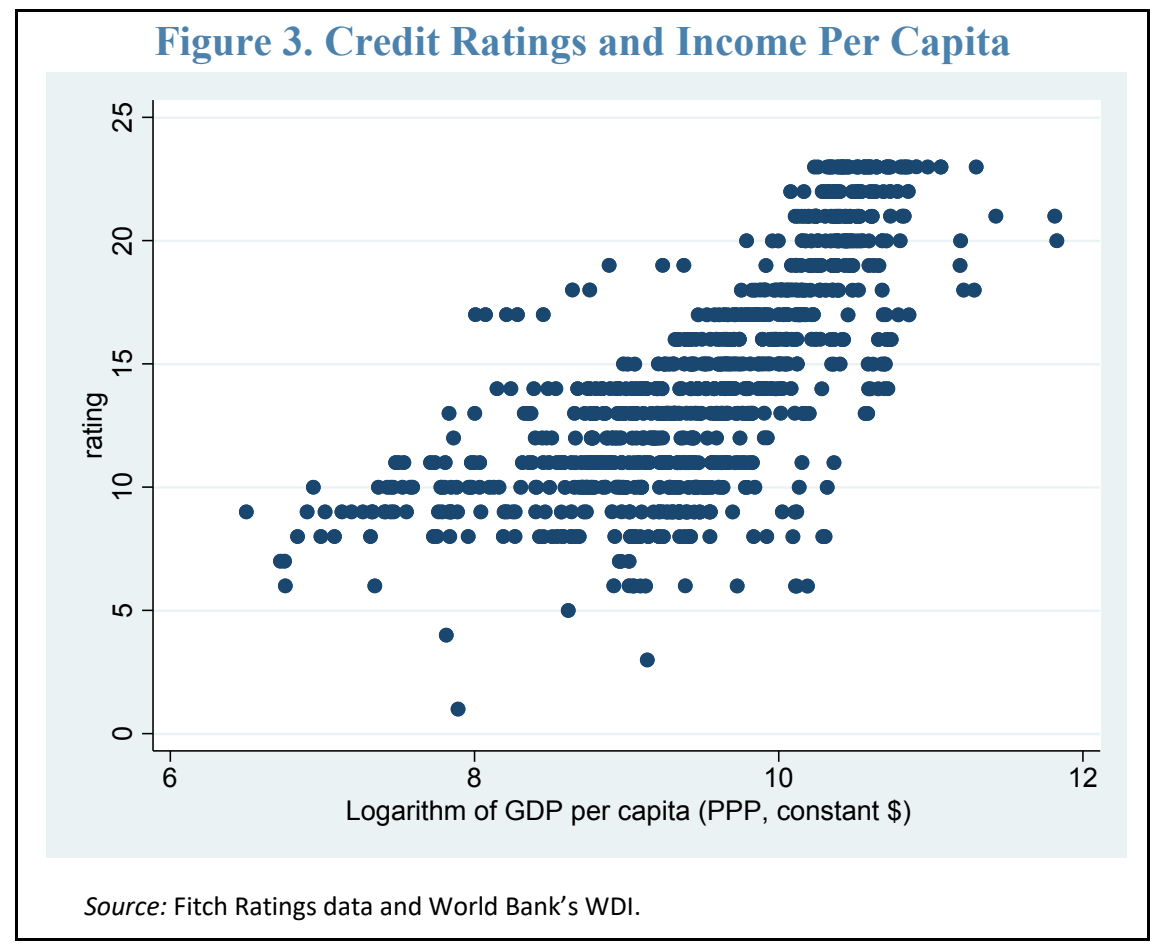

\section{Relevance of debt}

This section checks formally via a dominance analysis the relevance of debt for ratings, relative to the importance of other explanatory variables explored in our main regressions.

The dominance analysis results are reported in Annex I and suggest that public debt is indeed the key determinant of credit ratings. ${ }^{4}$ The analysis is based on the Panel OLS-Fixed Effect specification introduced in section III.E and presented in table 2 column 2. According to these results, debt dominates the other explanatory variables typically found to be relevant in empirical studies, such as GDP growth, inflation, VIX, interest rates, and even the level of GDP per capita (see Annex I).

\footnotetext{
${ }^{4}$ For discussion of dominance analysis see Budescu (1993), Grömping (2007), and Luchman (2014).
} 


\section{Rating data categorization}

The study employs the categorization of the 23 Fitch rating categories, where 1 refers to the lowest, and 23 to the highest credit rating category. For the purpose of splitting the sample when assessing differences across AEs and EMDEs, credit ratings are divided into three categories on the basis of standard conventions and data availability. As shown in Table 1, dividing the ratings into investment grade and non-investment grade (a standard distinction widely used by financial markets) and then dividing the investment grade group into two equal rating ranges, offers three categories, which divide the sample of AE and EMDEs quite conveniently. The green area in Table 1 depicts rating grades $\mathrm{DD}$ to $\mathrm{BB}+$ (or categorizations 1 to 13), which is named Non-Investment Grade (NIG) as it coincides with the grades below the investment grade threshold; for this category of rating, the available data belongs mainly to the EMDEs set of countries. ${ }^{5}$ Similarly, at the other extreme, the yellow area depicts the grades A+ to AAA (or categorizations 19 to 23), and is named High-Investment Grade (HIG) as it encompasses the higher half of the ratings categories in the investment grade group; this category of rating contains mainly AEs. Finally, there is an intermediate range of rating, which is above the investment-grade threshold, but encompasses the lower half of the investment grade group and-hence, it is named Low-Investment Grade (LIG). Such a category of rating is marked in white and encompasses both AE and EMDEs. These three categories will turn out to be useful when we will check the extent to which our nonlinearity explains the difference between AEs and EMDEs.

\footnotetext{
${ }^{5}$ In the context of rolling regressions with five consecutive credit rating grades, we impose a minimum of 30 country-year observations.
} 


\begin{tabular}{|c|c|c|c|c|c|}
\hline \multicolumn{6}{|c|}{$\begin{array}{c}\text { Table } 1 . \text { Credit Ratings Data } \\
\text { (Distribution across country groups) }\end{array}$} \\
\hline Rating & Category & ALL & AEs & EMDEs & Category \\
\hline AAA & 23 & 37 & 37 & & \\
\hline $\mathrm{AA}+$ & 22 & 25 & 25 & & High \\
\hline$A A$ & 21 & 36 & 35 & 1 & Investment \\
\hline AA- & 20 & 30 & 27 & 3 & Grade (HIG) \\
\hline $\mathrm{A}+$ & 19 & 26 & 18 & 8 & \\
\hline $\bar{A}$ & 18 & 30 & 16 & 14 & \\
\hline A- & 17 & 42 & 13 & 29 & Low \\
\hline $\mathrm{BBB}+$ & 16 & 50 & 15 & 35 & Investment \\
\hline BBB & 15 & 55 & 7 & 48 & Grade (LIG) \\
\hline BBB- & 14 & 62 & 6 & 56 & \\
\hline $\mathrm{BB}+$ & 13 & 68 & 9 & 59 & \\
\hline BB & 12 & 29 & & 29 & \\
\hline BB- & 11 & 68 & 1 & 67 & \\
\hline$B+$ & 10 & 47 & & 47 & \\
\hline B & 9 & 54 & 1 & 53 & \\
\hline B- & 8 & 38 & 4 & 34 & Non- \\
\hline $\mathrm{CCC}+$ & 7 & 5 & & 5 & Investment \\
\hline CCC & 6 & 10 & 2 & 8 & Grade \\
\hline CCC- & 5 & 1 & & 1 & \\
\hline $\mathrm{CC}$ & 4 & 1 & & 1 & \\
\hline $\mathrm{RD}$ & 3 & 1 & & 1 & \\
\hline DDD & 2 & & & & \\
\hline $\mathrm{DD}$ & 1 & 1 & & 1 & \\
\hline
\end{tabular}

\section{E. Empirical Methods}

\section{Panel Ordered Probit Regressions}

The ordered probit is the first method employed to investigate the impact of public debt on the probability of being placed in a better or worse credit rating category. For this purpose, the ordered probit regressions are based on the following specification:

$$
y_{i t}^{*}=\beta D_{i t}+\gamma X_{i t}+u_{i}+\epsilon_{i t}
$$

where the dependent variable $y_{i t}^{*}$ is the country $i$ 's credit rating category that can take 23 values corresponding to all credit rating grades from 1 to 23, (see Table 1), with the highest (23) indicating the best rating (AAA), in line with the first categorization of ratings explained in the previous section:

$$
y_{i}^{*}=\left\{\begin{array}{c}
1 \text { if } y_{i} \in D D \\
\ldots \\
23 \text { if } y_{i} \in A A A
\end{array}\right.
$$


and $D_{i t}$ stands for (gross or net) debt to GDP ratio of country $i$ in year $t$, while $X$ stands for the set of control variables for country $i$ in year $t$. The regression encompasses countryspecific fixed effects $\left(u_{i}\right)$.

\section{Panel OLS-Fixed Effects Regressions}

The results from ordered probit regressions are supplemented with standard panel OLS estimations allowing for country-specific fixed effects. The empirical specification is similar to the one used in the ordered probit:

$$
y_{i t}^{*}=\beta D_{i t}+\gamma X_{i t}+u_{i}+\epsilon_{i t}
$$

where $y_{i t}^{*}$ again is the country $i$ 's credit rating at time $t, D_{i t}$ stands for (gross or net) debt to GDP ratio of country $i$ in year $t$, and $X$ stands for the set of control variables for country $i$ in year $t$. The regression encompasses country-specific fixed effects $\left(u_{i}\right)$.

\section{EMPIRICAL RESUlTS}

\section{A. The negative relationship between debt and credit ratings}

The results in Table 2 confirm the findings of other empirical studies that higher public debt is associated with worse sovereign credit ratings. The results from the ordered probit that treats all 23 rating grades as categories of the dependent variable (i.e. one ordered probit category for each credit rating grade) in the first column indicates that an increase in debt ratio implies lower probability of being placed in a better rating category. These results are also fully consistent and similar in magnitude with the results reported in the second column from the fixed-effects panel regressions that include the same 23 rating grades as values for the dependent variable: they imply that an increase in the debt ratio by 10 percent of GDP is associated with almost half a notch lower credit rating. 


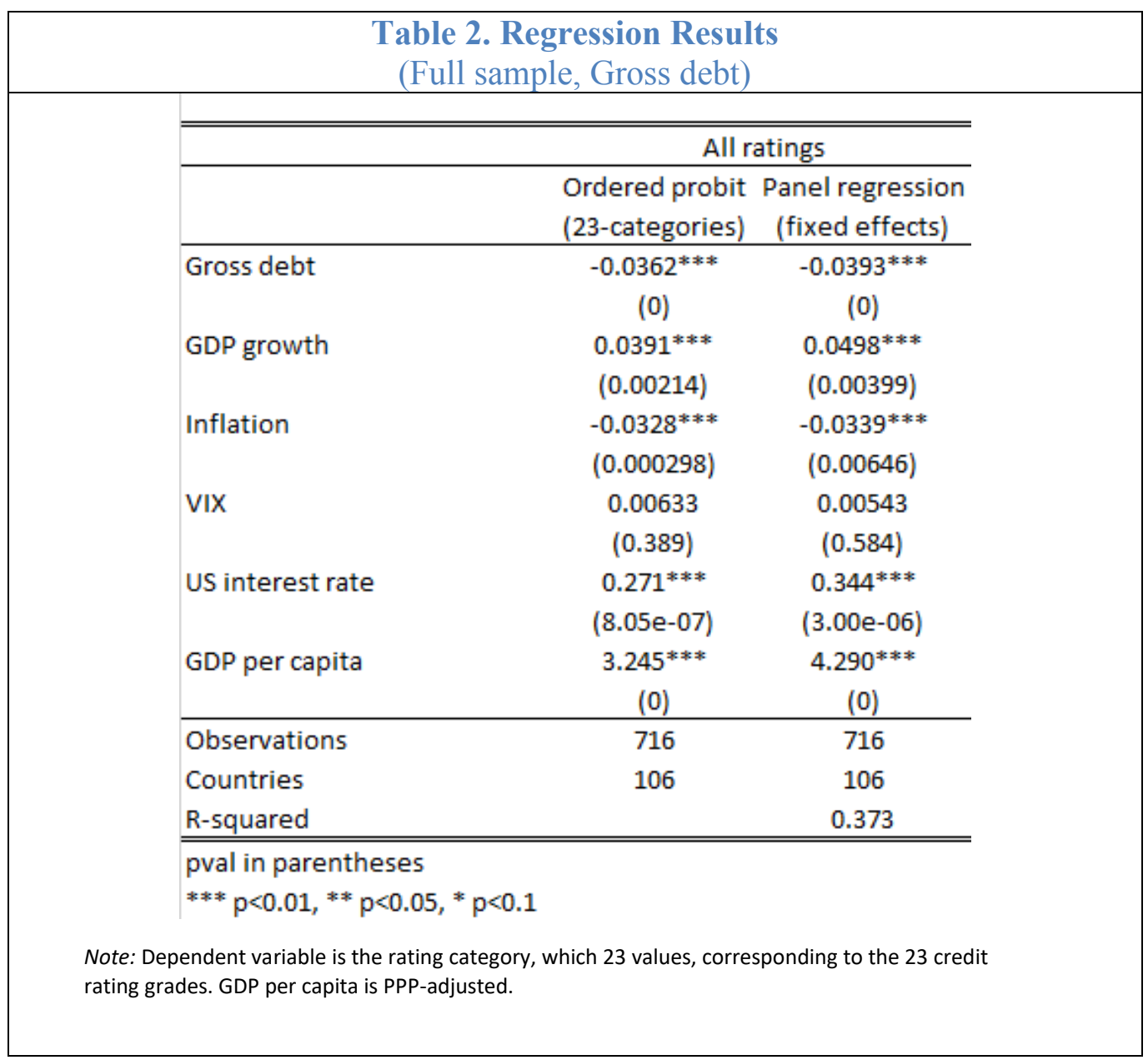

The specifications also include various controls, commonly employed in the literature, that have the expected effects. Higher level of GDP per capita and higher real GDP growth are associated with better sovereign credit ratings, while higher inflation with the opposite outcome. In addition, VIX and the US interest rates are included to control for global factors.

It is important to notice that the level of development as proxied by GDP per capita is highly significant, confirming the visual relation highlighted in section III.B. This is quite important as we will show that the residual difference between AEs and EMDEs, after controlling for GDP per capita, is actually apparent, and mainly related to the nonlinear nature of the relationship.

Having presented the findings of the general debt-ratings relationship in Table 2, the analysis now turns to the subtleties of this relationship. Is the negative impact of public debt on sovereign credit ratings uniform across rating grades and/or country groups? 


\section{B. Uncovering the non-linearity across credit rating grades}

The analysis in this section investigates the nonlinear behavior of the negative relationship between debt ratios and ratings across the credit rating spectrum - thereby, aiming at a better understanding of whether the "punishment" in terms of worse rating, related to the increase in public debt, affects countries differently.

\section{Panel ordered probit regressions}

Figure 4 presents the coefficient estimates from rolling ordered probit regressions based on windows of five credit rating grades at the time (as well as a polynomial trend line to show more clearly the pattern). ${ }^{6}$ For example, the first observation on the left of Figure 4 depicts the coefficient estimate from the ordered probit that only includes observations corresponding to rating grades from 4 to 8 (i.e. CC to B-), and so forth. The asymmetric Ushape implies that the negative impact of public debt on credit ratings is highly non-linear - it is weakest for the very low grades, somewhat higher for the very best grades, and highest for the "middle" grades.

There are possible explanations behind these findings. For countries with already very high risks and weakest credit ratings, the space for further downgrades due to debt increases seems to be limited. In addition, these countries may be affected by other factors (such as weak institutional settings and low policy credibility), which could be more important than debt compared to countries in the middle group of ratings. The countries with best credit ratings can be affected more by debt increases as their high standings require good fiscal discipline, among other issues. However, these countries may benefit from the opposite conditions, i.e. good institution and credibility, which may dampen the role of debt on ratings, compared to the third group, i.e. the one in the middle of the rating scale. The latter group of "middle graders" is composed of some of the best EMDEs and some of the lowerranked AEs and is found to be the most sensitive to debt increases - this is generally the group with close-to-investment grades and lower investment grades, encompassing the full LIG.

\footnotetext{
${ }^{6}$ Key findings are similar when using alternative credit rating windows (from 4-grade, 6-grade, and 7-grade rolling windows, results available upon request).
} 


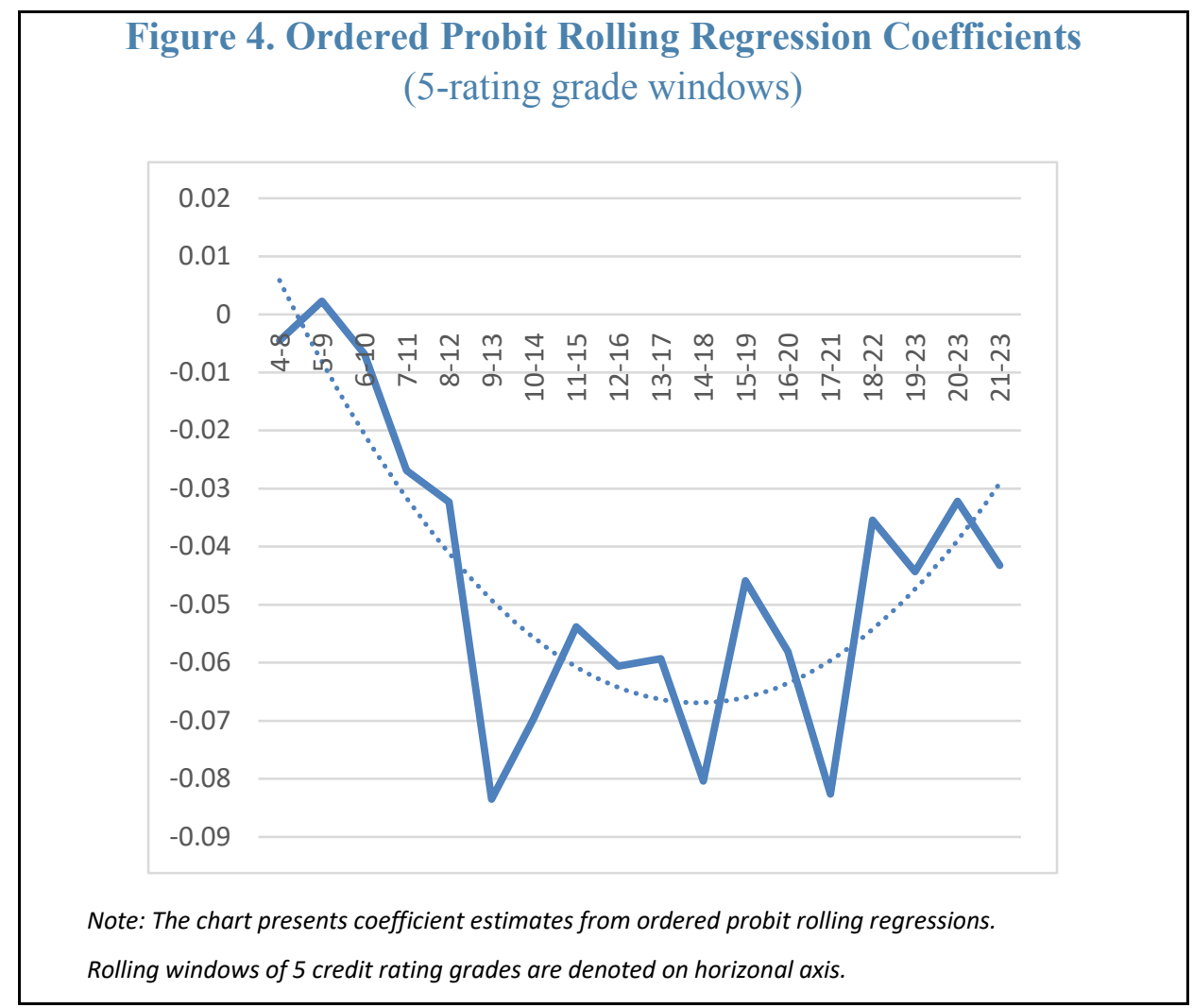

Figure 5 shows that, consistently with the above results, also the marginal probabilities of being placed in a different rating grade within the rolling 5-grade windows after the debt increase show the same non-linear pattern. Each of the five lines (marked as 1 to 5) in the left panel shows the marginal probability of falling in a particular grade (respectively first to fifth) within the respective 5-grade window (indicated in the horizontal axis), in response to an increase in debt. Within each 5-grade window (identified by each particular point on the horizontal axis) there is much higher probability of falling into the lower grades (grade 1 or 2) for credit grades in the middle of the credit rating distribution than in the extremes of such distribution. Correspondingly, the marginal probabilities of being placed in a better rating grade (grade 4 or 5), after a debt increase, is also much more negative for the middle area.

The right panel of Figure 5 shows such outcome more clearly, by averaging the two top and bottom lines, which represent the average marginal probabilities of falling in grades 1 and 2 or 4 and 5, respectively, in response to a debt increase. It is clear that in the middle range of ratings (i.e. windows broadly encompassing LIG), where the marginal probability is about 0.005 , a debt increase by 10 percent of GDP is associated with about a 5 percent higher (lower) probability of being placed into a worse (better) category within the corresponding 5grade window. For lower ratings (in the NIG group), the effect is smaller and eventually close to zero for the lowest ratings. For higher ratings (in the HIG group), the effect is somewhere in the middle, at around a 3 percent change in probability for a 10 percent change in debt. 
Figure 5. Marginal Probabilities from Ordered Probit Rolling Regressions

(5-rating grade windows)

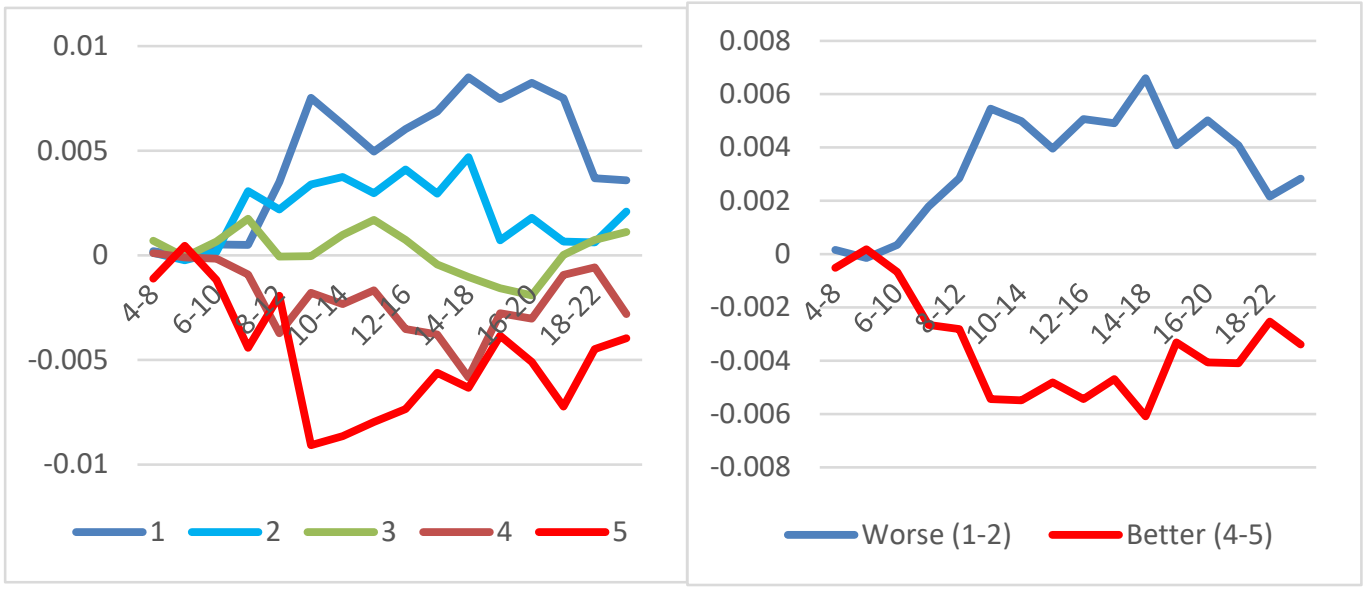

Note: The lines depict the marginal probabilities of being placed in different grades within the 5-grade windows, with the line marked by 1 corresponding to the lowest rating grade and the line marked by 5 to the best rating grade within the 5-grade window. In the right chart, the lines "Worse" ("Better") correspond to the average of lines 1 and 2 (4 and 5) in the left chart.

\section{Panel OLS-FE regressions}

These findings of non-linearity and asymmetric U-shape peculiar based on the ordered probit estimations are also evident in Figure 6, which presents the coefficient estimates from rolling panel OLS regressions with 5-grade rolling windows that allow for country-specific fixed effects. Similar to the case of ordered probit regressions, debt increases punish credit ratings of countries in the middle grades (mainly the LIG category) more than the countries in the extremes. Among the extremes, impact for observations with the worse credit rating grades is again smaller than the impact for those with the best credit grades.

In terms of quantifying the effect, in the middle range of ratings (about the LIG group), a debt increase by 10 percent of GDP is associated with a decline in rating of almost $1 / 2$ of a notch, which amounts to about 10-15 percent of one standard deviation. Similar as the ordered probit findings, the effect declines for lower ratings (in the NIG group), and eventually gets close to zero for the lowest ratings. For higher ratings (in the HIG group), the effect is again somewhere in the middle (about $1 / 4$ of a notch). 


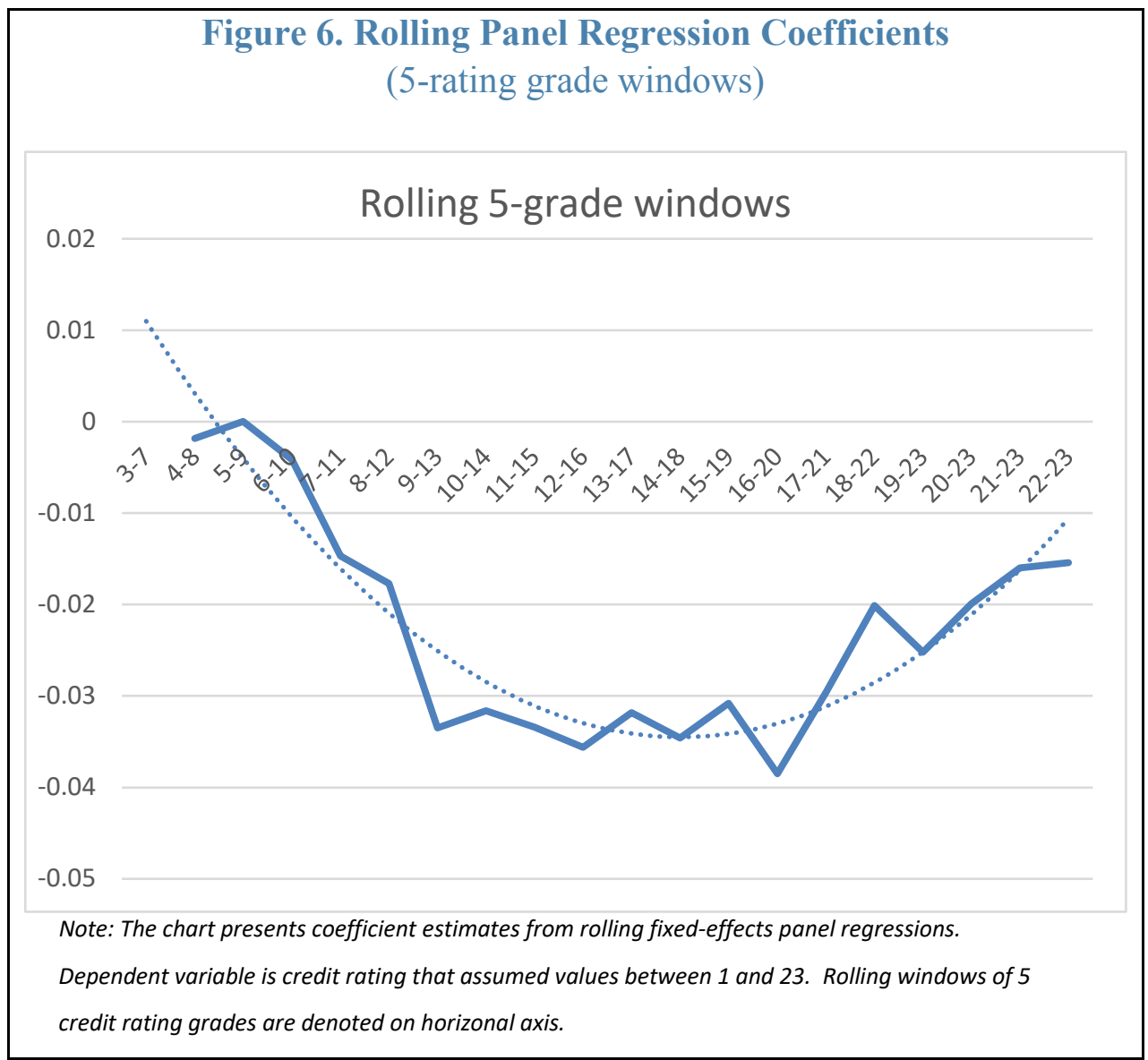

\section{Institutional Investor Index}

The Institutional Investor Index offers an alternative way of capturing investors' perception about countries' sovereign risk, thus allowing us to base our analysis on a different proxy for rating to be used as left hand side variable. The index, which ranges from 0 (worst) to 100 (best), is closely correlated with countries' credit ratings, as shown in Figure 7. 


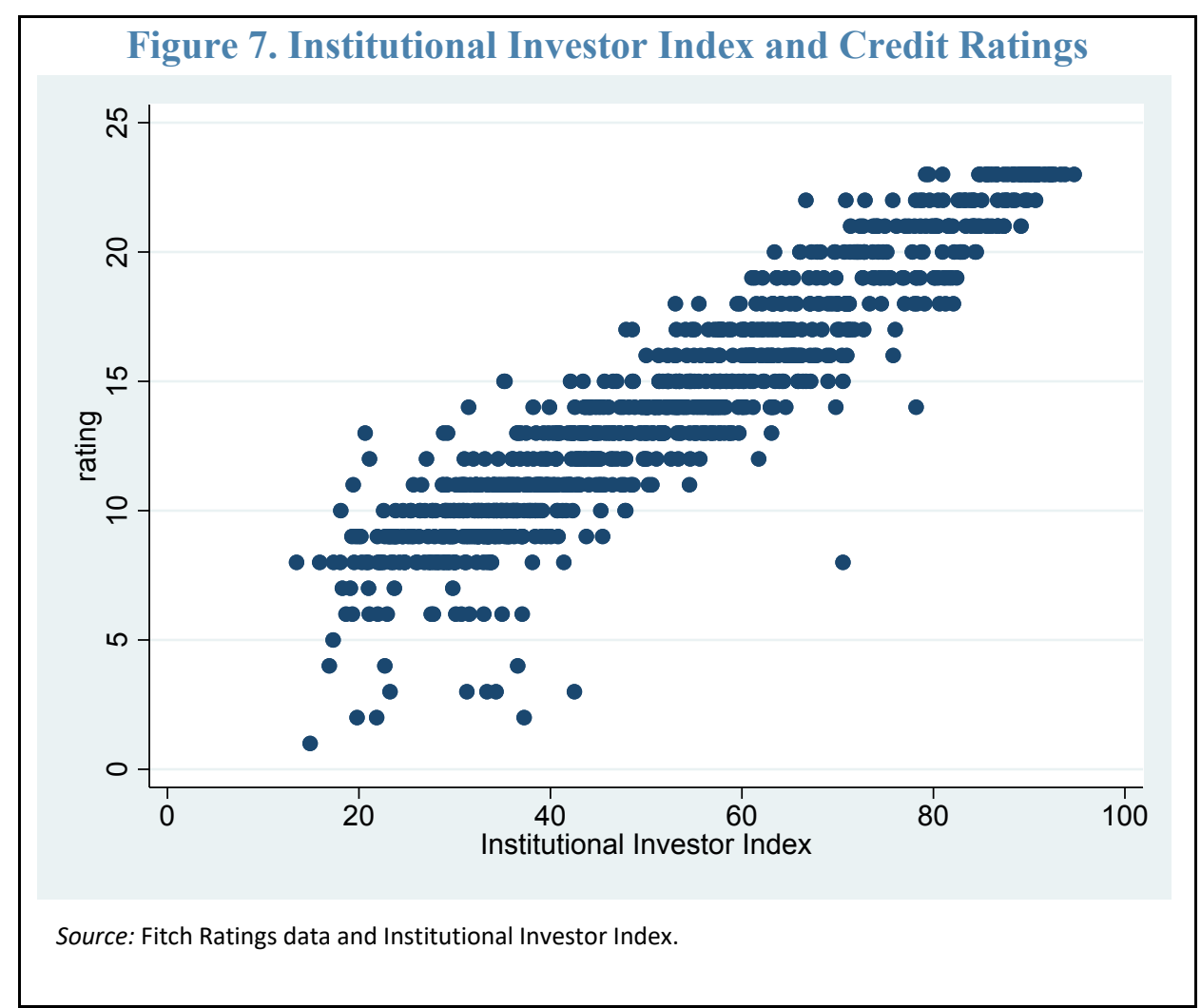

Th same nonlinear relation is supported by the indicators of sovereign creditworthiness offered by the Institutional Investors Index. Figure 8 indeed suggests a very similar pattern in the coefficient estimates from panel regressions (fixed effects) that replace the credit rating with the Institutional Investors Index as the dependent variable. Each point depicts the coefficient estimate from a 5-grade rolling window consistent with those used in Figures 4 and 6. 


\section{Figure 8. Rolling Panel Regression Coefficients for Institutional \\ Investor Index \\ (5-rating grade windows)}

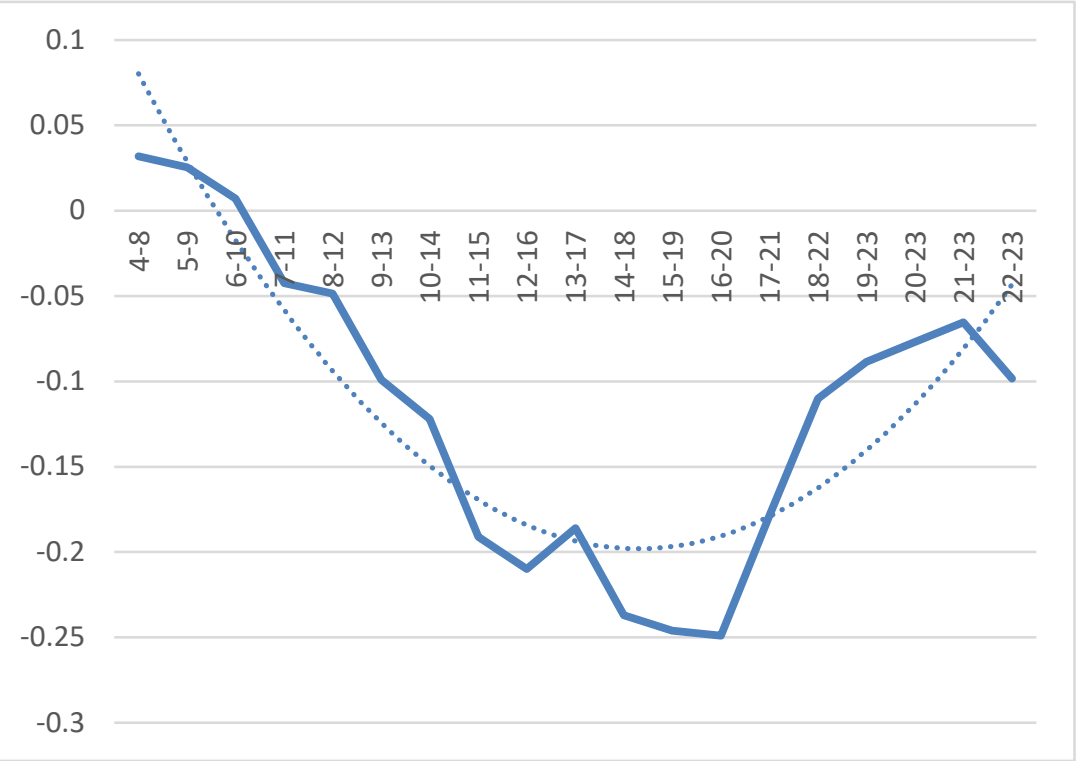

Note: The chart presents coefficient estimates from rolling fixed-effects panel regressions.

Dependent variable is Institutional Investor Index that assumed values between 0 and 100.

Rolling windows of 5 credit rating grades are denoted on horizonal axis.

An alternative check for the Institutional Investors Index is provided in Figure 9, which presents the coefficients from panel regressions in which the rolling windows are defined as 20-point ranges of Institutional Investors Index values, repeated every 5-points. This is meant to mimic the 5-grade rolling window, based on the Fitch rating, used above. The general finding of an asymmetric U-shape remains valid, with the "middle range" of countries again being punished the most in terms of Institutional Investors Index by debt increases. The results suggest that a debt increase of 10 percent of GDP is associated with a decline in the index by up to $2 \frac{1}{2}$ units, or about $10-15$ percent of one standard deviation, for the ratings in the middle range. ${ }^{7}$ The effect is halved for the group of best rating grades, and even smaller for the worse ratings.

\footnotetext{
${ }^{7}$ The results here based on the investor index are consistent with those from specification that have the credit ratings as the dependent variable, given the different ranges of the dependent variable (1-23 in the case of credit ratings and 0-100 in the case of the investor index): indeed, a commensurate debt increase is associated with a 10-15 percent of one standard deviation deterioration in both cases.
} 
Figure 9. Rolling Panel Regression Coefficients for Institutional Investor Index

(20-point windows)

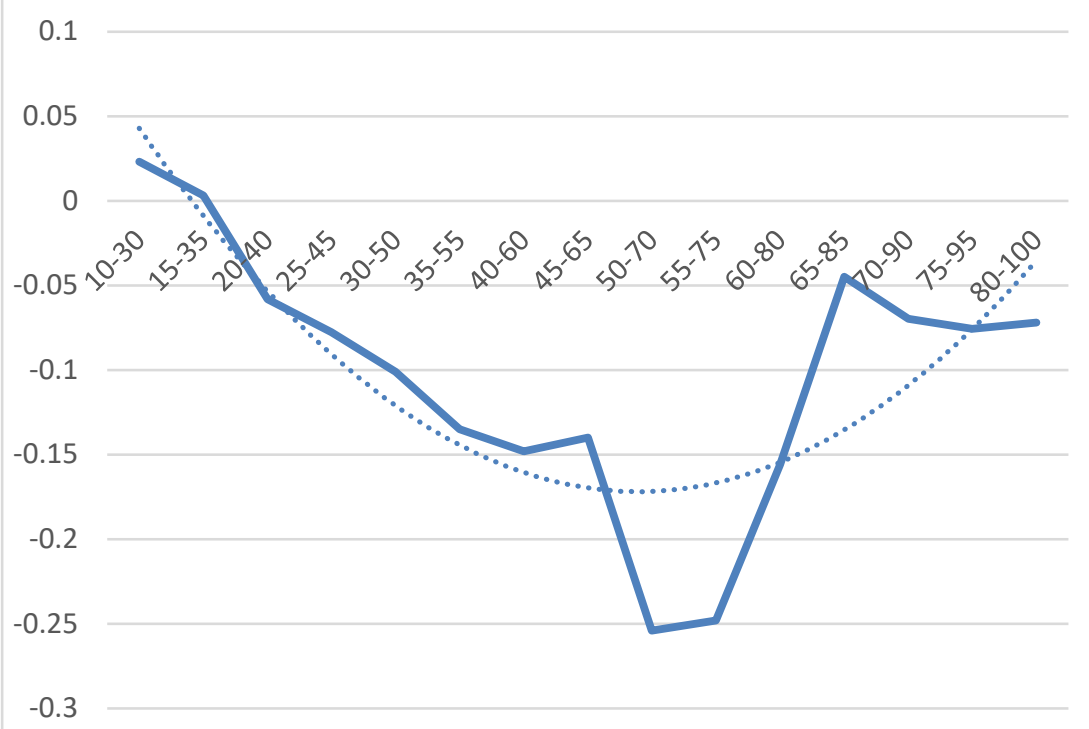

Note: The chart presents coefficient estimates from rolling fixed-effects panel regressions. Dependent variable is Institutional Investor Index that assumed values between 0 and 100.

Rolling windows of 5 credit rating grades are denoted on horizonal axis.

\section{CInternational Monetary Fund. Not for Redistribution}




\section{The non-linearity explains differences across AEs and EMDEs}

How important is the non-linearity explored in the previous section for explaining differences in public debt's impact on credit ratings across different groups of countries? Using the alternative empirical procedures described earlier, this section zooms in on the differences between advanced economies (AEs) and emerging and developing economies (EMDEs). For this purpose, Tables 3, 4, and 5 report results from the panel ordered probit regressions (dependent variable is credit rating with the 23 categories), fixed-effects panel regressions (dependent variable is credit rating that assumes the corresponding 23 values), and fixedeffects panel regressions that employ the Institutional Investor Index as the dependent variable.

The results in Table 3 confirm our earlier findings that higher debt levels are associated with lower credit ratings. Controlling for the standard set of variables and allowing for countryspecific fixed effects ${ }^{8}$, the results from ordered probit regressions in Table 3 suggest that an increase of gross is associated with a lower probability of being placed in a better credit rating grade. More interesting, even when controlling for GDP per capita, the results suggest that debt increases in AEs are associated with larger "punishments" in terms of lower credit ratings than EMDEs, a result that appears somewhat counterintuitive. Indeed, we would expect GDP per capita to account for the main differences across AEs and EMDEs, as visible from Figure 3; and, if anything, a commensurate increase in the public debt-to-GDP ratio should affect less countries that are widely believed to have better creditworthiness and to be more resilient (i.e. AEs). What lies behind this apparent difference across AEs and EMDEs?

Panel B shows how the answer is related to the nonlinearity uncovered in the previous section, by splitting the sample into the three groups of ratings highlighted in Table 1 . The results for different rating categories (NIG, LIG, and HIG) suggest that the effect of debt on credit ratings is similar for AEs and EMDEs that belong to the same rating category (and hence, similar rating grades), but quite different across rating categories. For instance, within LIG, the category that includes significant numbers of both AEs and EMDEs, the estimated coefficient for AEs $(-0.09)$ is very similar to the estimated coefficient for EMDEs (-0.1). However, in line with the rolling regression results presented in Figure 4, there are important differences in the coefficients among different rating categories, with the estimated effect being largest (most negative) for LIG, smallest for NIG (with a coefficient of about 0.02), and intermediate for HIG (about 0.04). Given that AEs are mainly distributed across LIG and HIG while EMDEs are mainly distributed across LIG and NIG (see Table 1), it is not surprising that the negative coefficient estimates are somewhat smaller for EMDEs than AEs, on average, when running separate regressions for each of these income groups.

\footnotetext{
${ }^{8}$ The standard control variables have the expected effects, with higher GDP per capita and better growth performance being associated with better ratings, and higher inflation with lower ratings, while the effect of VIX is insignificant.
} 
Hence, two factors explain the apparent difference in the effect of debt on ratings for AEs and EMDEs (and seemingly counterintuitive result) visible in Table 3: the nonlinear relation of debt on ratings across ratings grades (i.e. different levels of sensitivity to debt increases across rating grades), and the uneven distribution of AEs and EMDEs across credit rating grades.

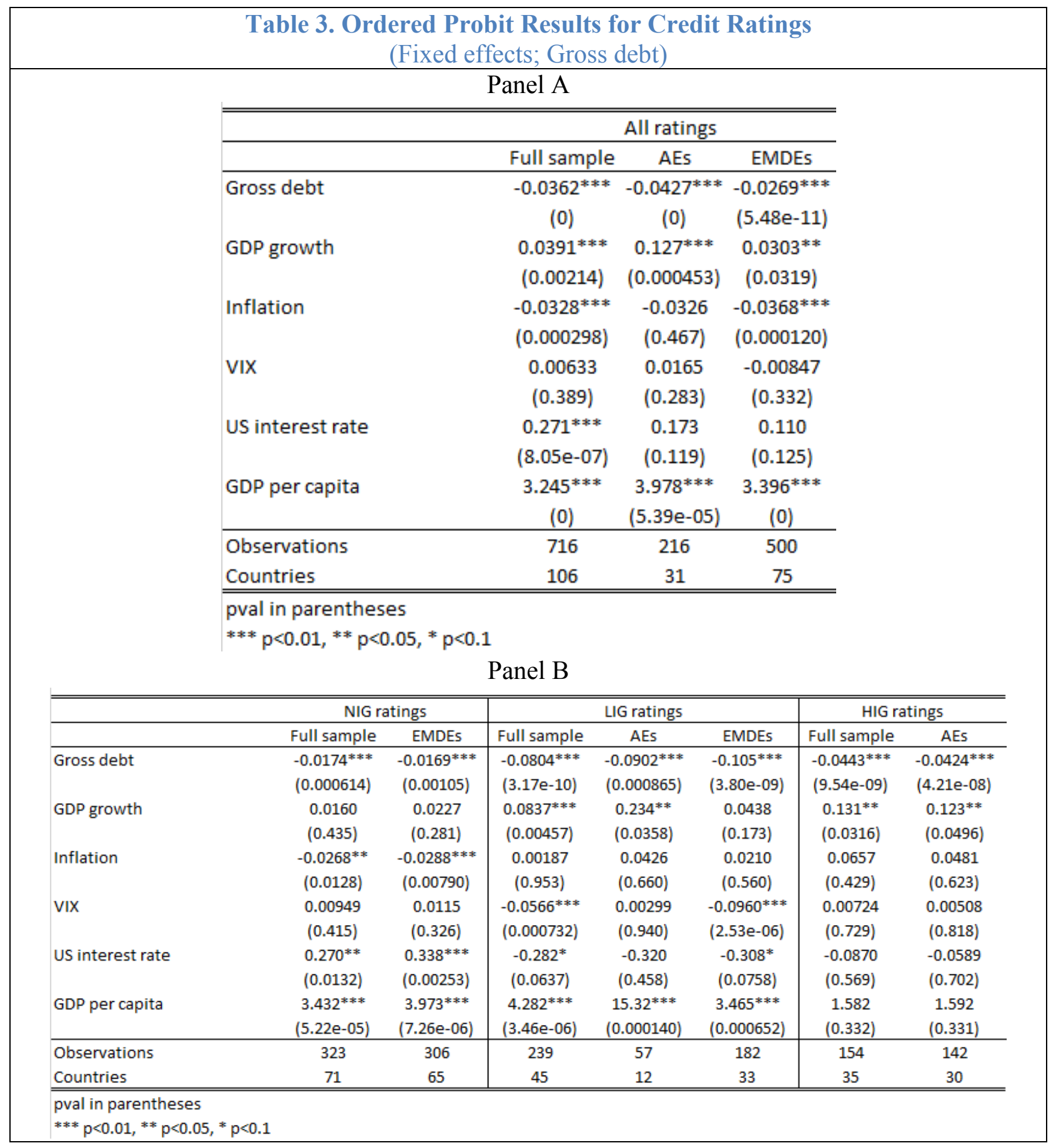


Table 4 presents results from panel regressions (based on 23-value dependent variable and allowing for country-specific fixed effects) that confirm the findings from the ordered probit regressions: the non-linearity of the debt-ratings relationship across credit rating grades explains the differences between AEs and EMDEs. Again, the effect of debt on credit ratings is found to be stronger for AEs than for EMDEs, for the respective general sample encompassing different ratings groups. As in the case of ordered probit regressions, Panel B of Table 4 suggests that the effect of debt on credit ratings is similar for AEs and EMDEs that belong to the same rating category; but differs considerable across rating categories. Within the category that includes significant numbers of both AEs and EMDEs (LIG), the estimated effects for AEs and EMDEs are very similar (-0.030 for AEs vs.-0.038 for EMDEs). However, important differences among the rating categories remain-LIG have largest estimated effect, HIG smaller, and NIG have the smallest effect, in absolute terms. These findings are fully consistent with the ordered probit results in Table 3 and the results from various rolling regressions in Figures 4 and 6 and suggest that the differences in the estimated effects between AEs and EMDEs are explained by the differences in their distributions across rating categories, coupled with the nonlinear relationship.

When quantifying the effects for the average country in each of the three ratings group (NIG, LIG, HIG), we find that a debt increase of 10 percent of GDP is associated with almost $1 / 2$ of a notch lower rating for LIG, which are consistent with the results from Figure 6 . The effect is smaller for the lowest rating in NIG group, about 1/6 of a notch, and it is somewhere in the middle (about $1 / 4$ of a notch) for the best credit rating in HIG group.

It is quite interesting to notice that the nonlinear relation is also consistent with a breakdown of the EMDEs into different regional groups (which is an exogenous breakdown). Indeed, different average ratings across regions are related to different relations between debt and ratings: Annex II shows (both in a Table and in a Figure) the average rating for each country grouping across the regression sample, as well as the coefficient estimates from regression equivalent to the one in column 1 of Table 4, but run for different regional samples. Quite remarkably, EMDEs regions with higher average rating (like Emerging Asia, Emerging Europe, and MENA) tend to have a higher slope than EMDEs regions with lower average ratings (such as CIS and SSA; with the exception of LAC that behaves closer to countries with higher ratings), a result fully consistent with the main findings of nonlinearity. ${ }^{9}$

\footnotetext{
${ }^{9}$ A similar regional pattern emerges when exploring the partial regression plot for debt on ratings—controlling for the other variables (Avplot in Stata) as from the same specification in column 1 of Table 4-but calculated for each region separately (results available upon request).
} 


\begin{tabular}{|c|c|c|c|c|c|c|c|}
\hline \multicolumn{8}{|c|}{$\begin{array}{l}\text { Table 4. Panel Regression Results for Credit Ratings } \\
\text { (Fixed effects; Gross debt) }\end{array}$} \\
\hline \multicolumn{7}{|c|}{ Panel A } & \\
\hline & & & \multicolumn{4}{|c|}{ All ratings } & \\
\hline & & & Full sample & AEs & \multicolumn{2}{|c|}{ EMDEs } & \\
\hline & \multicolumn{2}{|l|}{ Gross debt } & $\begin{array}{l}-0.0393^{* * *} \\
(0)\end{array}$ & $\begin{array}{l}-0.0533 * * * \\
(0)\end{array}$ & $\begin{array}{l}-0.02 \\
(3.46\end{array}$ & $-0.0235^{* * *}$ & \\
\hline & \multicolumn{2}{|l|}{ GDP growth } & $\begin{array}{l}0.0498^{* * *} \\
(0.00399)\end{array}$ & $\begin{array}{c}0.237^{* * *} \\
(1.93 e-05)\end{array}$ & $\begin{array}{l}0.0 \\
10.2\end{array}$ & 191 & \\
\hline & \multicolumn{2}{|l|}{ Inflation } & $\begin{array}{l}-0.0339 * * * \\
(0.00646)\end{array}$ & $\begin{array}{l}-0.0226 \\
(0.752)\end{array}$ & $\begin{array}{r}-0.03 \\
(0.06\end{array}$ & $\begin{array}{l}12 * * * \\
0207)\end{array}$ & \\
\hline & \multicolumn{2}{|l|}{ VIX } & $\begin{array}{l}0.00543 \\
(0.584)\end{array}$ & $\begin{array}{r}0.0245 \\
(0.293)\end{array}$ & $\begin{array}{l}-0.0 \\
(0.2\end{array}$ & $\begin{array}{l}108 \\
247)\end{array}$ & \\
\hline & \multicolumn{2}{|l|}{ US interest rate } & $\begin{array}{c}0.344^{* * *} \\
(3.00 \mathrm{e}-06)\end{array}$ & $\begin{array}{c}0.300^{*} \\
(0.0745)\end{array}$ & $\begin{array}{l}0 . \\
0 .\end{array}$ & $\begin{array}{l}120 \\
116)\end{array}$ & \\
\hline & \multicolumn{2}{|l|}{ GDP per capita } & $\begin{array}{l}4.290^{* * * *} \\
(0)\end{array}$ & $\begin{array}{c}7.370 * * * \\
(2.97 e-06)\end{array}$ & 3.10 & $\begin{array}{l}5^{* * *} \\
0)\end{array}$ & \\
\hline & \multicolumn{2}{|l|}{ Constant } & $\begin{array}{l}-25.87^{* * *} \\
(5.99 \mathrm{e}-07)\end{array}$ & $\begin{array}{l}-55.79 * * * \\
(0.000837)\end{array}$ & $\begin{array}{l}-15.0 \\
(0.00\end{array}$ & $0823)$ & \\
\hline & \multicolumn{2}{|l|}{ Observations } & 716 & 216 & & 00 & \\
\hline & \multicolumn{2}{|l|}{ R-squared } & 0.373 & 0.563 & & 307 & \\
\hline & Countries & & 106 & 31 & & 5 & \\
\hline & $\begin{array}{l}\text { pval in parentheses } \\
* * * p<0.01, * * p<0.05\end{array}$ & $* p<0.1$ & & & & & \\
\hline & & & Panel B & & & & \\
\hline & NIG ra & tings & & LIG ratings & & HIG r & tings \\
\hline & Full sample & EMDEs & Full sample & $\mathrm{AEs}$ & EMDEs & Full sample & AEs \\
\hline Gross debt & $\begin{array}{c}-0.0153^{* * *} \\
(0.00365)\end{array}$ & $\begin{array}{c}-0.0147^{* * *} \\
(0.00487)\end{array}$ & $\begin{array}{l}-0.0346 * * * \\
(4.13 e-07)\end{array}$ & $\begin{array}{c}-0.0303^{* *} \\
(0.0239)\end{array}$ & $\begin{array}{c}-0.0381^{* * *} \\
(2.65 \mathrm{e}-06)\end{array}$ & $\begin{array}{c}-0.0252^{* * *} \\
(1.78 \mathrm{e}-09)\end{array}$ & $\begin{array}{c}-0.0248^{* * *} \\
(1.34 \mathrm{e}-08)\end{array}$ \\
\hline GDP growth & $\begin{array}{l}0.00303 \\
(0.887)\end{array}$ & $\begin{array}{l}0.00449 \\
(0.833)\end{array}$ & $\begin{array}{l}0.0360^{* *} \\
(0.0456)\end{array}$ & $\begin{array}{c}0.115^{*} \\
(0.0881)\end{array}$ & $\begin{array}{l}0.0117 \\
(0.508)\end{array}$ & $\begin{array}{c}0.0698^{* *} \\
(0.0410)\end{array}$ & $\begin{array}{l}0.0676^{*} \\
(0.0669)\end{array}$ \\
\hline Inflation & $\begin{array}{l}-0.0218^{*} \\
(0.0568)\end{array}$ & $\begin{array}{c}-0.0224^{* *} \\
(0.0459)\end{array}$ & $\begin{array}{l}-0.0122 \\
(0.540)\end{array}$ & $\begin{array}{c}-0.00327 \\
(0.959)\end{array}$ & $\begin{array}{l}0.00192 \\
(0.923)\end{array}$ & $\begin{array}{l}0.0343 \\
(0.463)\end{array}$ & $\begin{array}{l}0.0285 \\
(0.608)\end{array}$ \\
\hline VIX & $\begin{array}{c}-0.000931 \\
(0.939)\end{array}$ & $\begin{array}{l}0.000545 \\
(0.964)\end{array}$ & $\begin{array}{l}-0.0292 * * * \\
(0.00380)\end{array}$ & $\begin{array}{l}0.0148 \\
(0.519)\end{array}$ & $\begin{array}{l}-0.0460^{* * *} \\
(2.35 \mathrm{e}-05)\end{array}$ & $\begin{array}{c}-0.000560 \\
(0.960)\end{array}$ & $\begin{array}{l}-0.00109 \\
(0.929)\end{array}$ \\
\hline US interest rate & $\begin{array}{l}0.229 * * \\
(0.0372)\end{array}$ & $\begin{array}{l}0.270^{* *} \\
(0.0133)\end{array}$ & $\begin{array}{l}-0.0300 \\
(0.725)\end{array}$ & $\begin{array}{c}-0.00208 \\
(0.992)\end{array}$ & $\begin{array}{l}-0.0451 \\
(0.613)\end{array}$ & $\begin{array}{l}-0.0922 \\
(0.275)\end{array}$ & $\begin{array}{c}-0.0822 \\
(0.364)\end{array}$ \\
\hline GDP per capita & $\begin{array}{c}2.748^{* * *} \\
(0.000586)\end{array}$ & $\begin{array}{c}2.993^{* * *} \\
(0.000158)\end{array}$ & $\begin{array}{c}2.525 * * * \\
(3.77 \mathrm{e}-06)\end{array}$ & $\begin{array}{c}6.954^{* * *} \\
(0.000380)\end{array}$ & $\begin{array}{c}1.864^{* * *} \\
(0.000641)\end{array}$ & $\begin{array}{c}0.618 \\
(0.484)\end{array}$ & $\begin{array}{c}0.631 \\
(0.522)\end{array}$ \\
\hline Constant & $\begin{array}{l}-14.00^{*} \\
(0.0612) \\
\end{array}$ & $\begin{array}{l}-16.26^{* *} \\
(0.0269) \\
\end{array}$ & $\begin{array}{l}-6.815 \\
(0.218) \\
\end{array}$ & $\begin{array}{l}-53.01 * * * \\
(0.00781) \\
\end{array}$ & $\begin{array}{l}-0.0880 \\
(0.987) \\
\end{array}$ & $\begin{array}{c}16.41^{*} \\
(0.0877)\end{array}$ & $\begin{array}{c}16.48 \\
(0.124)\end{array}$ \\
\hline Observations & 323 & 306 & 239 & 57 & 182 & 154 & 142 \\
\hline R-squared & 0.162 & 0.182 & 0.366 & 0.569 & 0.383 & 0.366 & 0.349 \\
\hline Countries & 71 & 65 & 45 & 12 & 33 & 35 & 30 \\
\hline $\begin{array}{l}\text { pval in parenthe } \\
* * * p<0.01, * * p<\end{array}$ & $\begin{array}{l}.05, * p<0.1 \\
.05\end{array}$ & & & & & & \\
\hline
\end{tabular}


Finally, Table 5 reports results from panel regressions that replace the rating variable/grade with the Institutional Investor Index as the dependent variable of interest. Similar as the results from ordered probit and panel regressions, it confirms the negative impact of public debt on sovereign credit ratings. As seen before, the effect is the strongest for LIG, followed by HIG, and NIG, explaining the differences already seen between AEs and EMDEs.

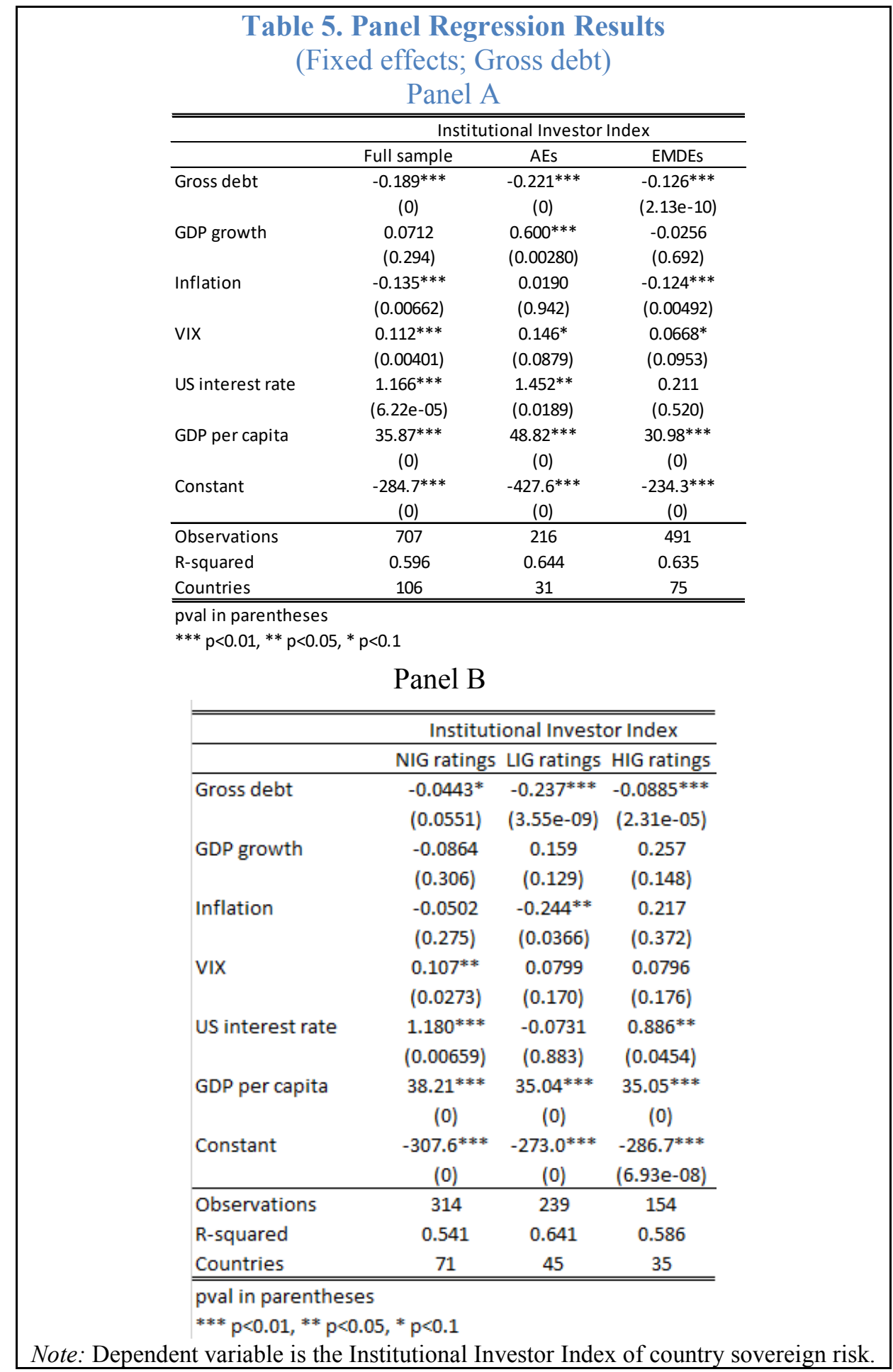




\section{ROBUSTNESS}

This section investigates the robustness of the empirical findings to alternative specifications. First, gross debt is replaced by net debt as the relevant public debt variable. Second, given the attention paid to diversification in some credit ratings reports (see, for instance, Fitch Ratings report for Chile from March 2019), the analysis includes an indicator of export diversification. Third, the analysis accounts for the persistence of credit ratings by including lagged dependent variables in the empirical specification. Fourth, it checks the sensitivity of the key findings when ordered logit is employed instead of ordered probit.

\section{A. Net Debt}

Tables $6,7,8$, and 9 show the sensitivity of the results to the replacement of gross debt by net debt, which may provide additional information about the countries' creditworthiness. Table 6 shows that the negative relationship between debt and credit ratings remains intact in the overall sample. In addition, similar as in Table 2, the results from ordered probit and panel regressions are virtually identical. Tables 7 and 8 provide the full estimation results from the ordered probit and panel regressions for various country groups and credit rating categories. All key results are robust to the replacement of gross debt by the net debt variable. Namely: the effect of debt on credit ratings continues to be larger for AEs than for EMDEs; the effect differs across credit rating categories and remains the strongest for LIG, followed by HIG, and NIG; but, within the LIG group the effect is virtually the same for AEs and EMDEs. Finally, the results for the Institutional Investor Index from Table 5 are confirmed by the results in Table 9, where the effect remains the strongest for LIG, smaller for HIG, and the smallest for NIG.

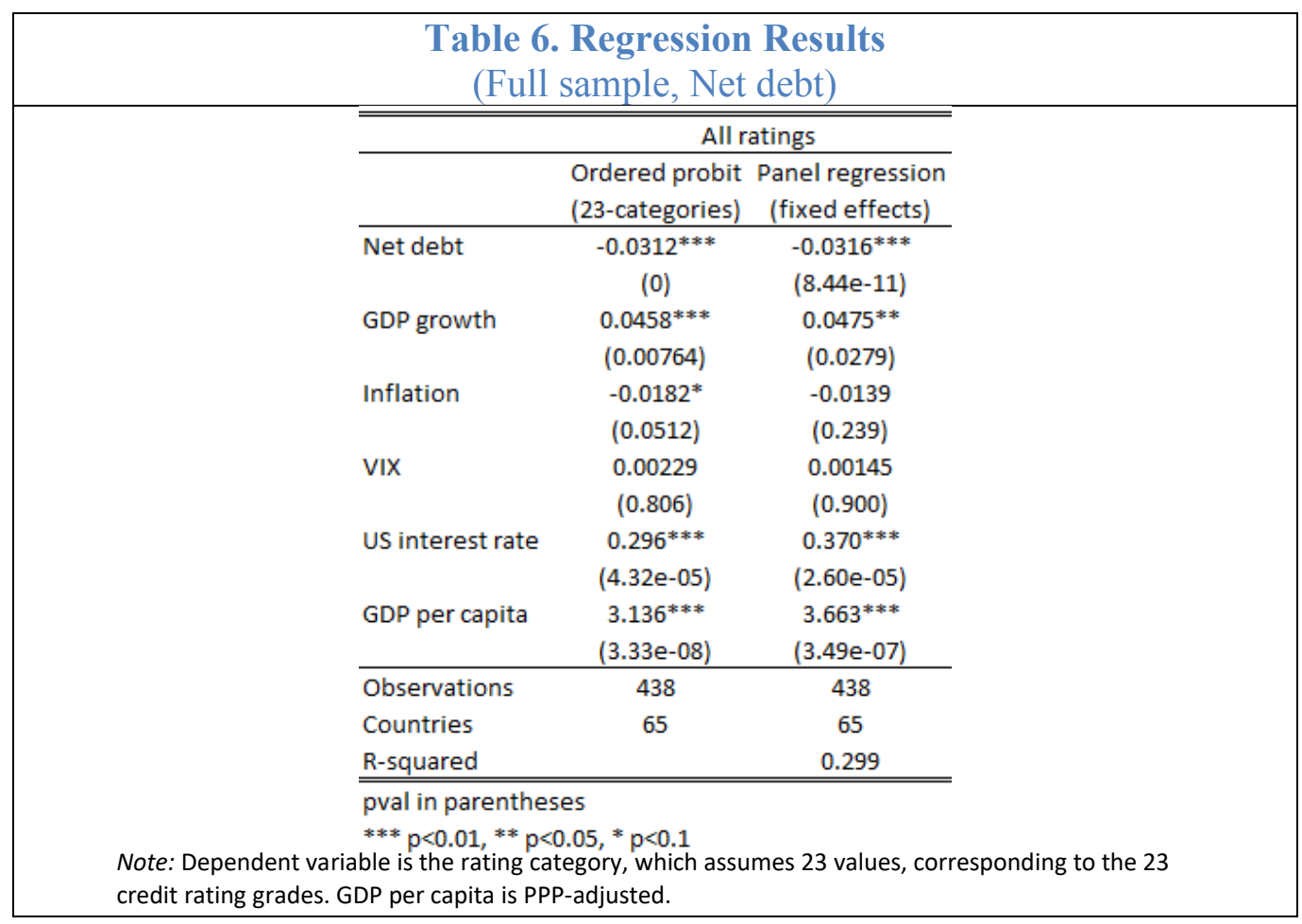




\begin{tabular}{|c|c|c|c|c|c|c|c|}
\hline \multicolumn{8}{|c|}{$\begin{array}{l}\text { Table 7. Ordered Probit Results for Credit Ratings } \\
\text { (Fixed effects; Net debt) }\end{array}$} \\
\hline & \multicolumn{6}{|c|}{ Panel A } & \\
\hline & & & \multicolumn{4}{|c|}{ All ratings } & \\
\hline & & & Full sample & ample & Es & EMDEs & \\
\hline & \multicolumn{2}{|l|}{ Net debt } & \multicolumn{2}{|c|}{$\begin{array}{c}-0.0312^{* * *} \\
(0)\end{array}$} & $-0.0447^{* * *}$ & $-0.0249^{* * *}$ & \\
\hline & \multicolumn{2}{|c|}{ GDP growth } & \multicolumn{2}{|c|}{$\begin{array}{l}0.0458^{* * *} \\
(0.00764)\end{array}$} & $\begin{array}{ll}2^{* * *} & 0.0 \\
e-05) & (0 .\end{array}$ & $\begin{array}{l}395^{* *} \\
.0389)\end{array}$ & \\
\hline & \multicolumn{2}{|l|}{ Inflation } & \multicolumn{2}{|c|}{$\begin{array}{l}-0.0182^{*} \\
(0.0512)\end{array}$} & $\begin{array}{l}498 \\
452)\end{array}$ & -0.0106 & \\
\hline & \multicolumn{2}{|l|}{ VIX } & \multicolumn{2}{|c|}{$\begin{array}{c}0.00229 \\
(0.806)\end{array}$} & $\begin{array}{l}96^{* *} \\
361)\end{array}$ & $\begin{array}{l}.0119 \\
.291)\end{array}$ & \\
\hline & \multicolumn{2}{|c|}{ US interest rate } & \multicolumn{2}{|c|}{$\begin{array}{c}0.296^{* * *} \\
(4.32 \mathrm{e}-05)\end{array}$} & $\begin{array}{l}0.0380 \\
(0.775)\end{array}$ & 0.0308 & \\
\hline & \multicolumn{2}{|c|}{ GDP per capita } & \multicolumn{2}{|c|}{$\begin{array}{c}3.136^{* * *} \\
(3.33 \mathrm{e}-08)\end{array}$} & $\begin{array}{l}624 \\
558)\end{array}$ & $\begin{array}{l}64^{* * *} \\
5 e-06)\end{array}$ & \\
\hline & \multirow{2}{*}{\multicolumn{2}{|c|}{$\begin{array}{l}\text { Observations } \\
\text { Countries }\end{array}$}} & 438 & \multicolumn{2}{|c|}{142} & 296 & \\
\hline & & & & 55 & 2 & 43 & \\
\hline & $\begin{array}{l}\text { pval in pa } \\
* * * p<0.01\end{array}$ & $\begin{array}{l}\text { entheses } \\
{ }^{* *} p<0.05, *\end{array}$ & $p<0.1$ & & & & \\
\hline & & & Panel & & & & \\
\hline & & NIG re & atings & LIG rat & tings & HIG ra & atings \\
\hline & & Full sample & EMDEs & Full sample & EMDES & Full sample & AEs \\
\hline Net debt & & $\begin{array}{c}-0.0161^{* * * *} \\
(0.00979)\end{array}$ & $\begin{array}{c}-0.0181^{* * *} \\
(0.00455)\end{array}$ & \begin{tabular}{|l|}
$-0.114^{* * * *}$ \\
$(8.72 \mathrm{e}-08)$
\end{tabular} & $\begin{array}{l}-0.124^{* * *} \\
(1.90 \mathrm{e}-07)\end{array}$ & \begin{tabular}{|c|}
$-0.0401^{* * *}$ \\
$(9.52 \mathrm{e}-07)$
\end{tabular} & $\begin{array}{l}-0.0388^{* * *} \\
(2.54 \mathrm{e}-06)\end{array}$ \\
\hline GDP growth & & $\begin{array}{l}0.0291 \\
(0.339)\end{array}$ & $\begin{array}{l}0.0200 \\
(0.517)\end{array}$ & $\begin{array}{l}0.0673^{*} \\
(0.0674)\end{array}$ & $\begin{array}{l}0.0532 \\
(0.160)\end{array}$ & $\begin{array}{l}0.145^{* *} \\
(0.0496)\end{array}$ & $\begin{array}{l}0.148^{* *} \\
(0.0495)\end{array}$ \\
\hline Inflation & & $\begin{array}{l}-0.0118 \\
(0.257)\end{array}$ & $\begin{array}{l}-0.0117 \\
(0.265)\end{array}$ & $\begin{array}{l}-0.0231 \\
(0.589)\end{array}$ & $\begin{array}{l}-0.0289 \\
(0.519)\end{array}$ & $\begin{array}{c}0.130 \\
(0.248)\end{array}$ & $\begin{array}{c}0.136 \\
(0.233)\end{array}$ \\
\hline VIX & & $\begin{array}{l}0.0186 \\
(0.228)\end{array}$ & $\begin{array}{l}0.0181 \\
(0.240)\end{array}$ & $\begin{array}{l}-0.114^{* * *} \\
(2.97 \mathrm{e}-06)\end{array}$ & $\begin{array}{l}-0.123^{* * *} \\
(3.21 \mathrm{e}-06)\end{array}$ & $\begin{array}{l}0.0224 \\
(0.306)\end{array}$ & $\begin{array}{l}0.0247 \\
(0.289)\end{array}$ \\
\hline US interest rate & & $\begin{array}{l}0.382^{* *} \\
(0.0179)\end{array}$ & $\begin{array}{l}0.360^{* *} \\
(0.0261)\end{array}$ & $\begin{array}{l}-0.464^{* *} \\
(0.0191)\end{array}$ & $\begin{array}{l}-0.463^{* *} \\
(0.0299)\end{array}$ & $\begin{array}{l}-0.0595 \\
(0.722)\end{array}$ & $\begin{array}{l}-0.0540 \\
(0.750)\end{array}$ \\
\hline GDP per capita & & $\begin{array}{l}3.621^{* * *} \\
(0.00126) \\
\end{array}$ & $\begin{array}{l}3.458^{* * *} \\
(0.00213) \\
\end{array}$ & $\begin{array}{l}3.245^{* * *} \\
(0.00427) \\
\end{array}$ & $\begin{array}{l}2.939^{* *} \\
(0.0126) \\
\end{array}$ & $\begin{array}{c}1.375 \\
(0.511)\end{array}$ & $\begin{array}{c}1.319 \\
(0.529)\end{array}$ \\
\hline Observations & & 181 & 173 & 142 & 117 & 115 & 109 \\
\hline Countries & & 38 & 35 & 27 & 21 & 23 & 20 \\
\hline
\end{tabular}

CInternational Monetary Fund. Not for Redistribution 
Table 8. Panel Regression Results for Credit Ratings (Fixed effects; Net debt)

Panel A

\begin{tabular}{lccc}
\hline \hline & \multicolumn{3}{c}{ All ratings } \\
\hline Net debt & Full sample & AEs & EMDEs \\
GDP growth & $-0.0316^{* * *}$ & $-0.0484^{* * *}$ & $-0.0208^{* * *}$ \\
& $(8.44 \mathrm{e}-11)$ & $(1.04 \mathrm{e}-07)$ & $(0.000109)$ \\
Inflation & $0.0475^{* *}$ & $0.277^{* * *}$ & 0.0295 \\
& $(0.0279)$ & $(7.49 \mathrm{e}-05)$ & $(0.147)$ \\
VIX & -0.0139 & -0.00805 & -0.00712 \\
& $(0.239)$ & $(0.931)$ & $(0.488)$ \\
US interest rate & 0.00145 & $0.0445^{*}$ & -0.0112 \\
& $(0.900)$ & $(0.0732)$ & $(0.347)$ \\
GDP per capita & $0.370^{* * *}$ & 0.0853 & 0.0582 \\
& $(2.60 \mathrm{e}-05)$ & $(0.625)$ & $(0.591)$ \\
Constant & $3.663^{* * *}$ & -0.633 & $3.147^{* * *}$ \\
& $(3.49 \mathrm{e}-07)$ & $(0.753)$ & $(1.33 \mathrm{e}-05)$ \\
& $-20.76^{* * *}$ & 27.16 & $-15.92^{* *}$ \\
& $(0.00394)$ & $(0.209)$ & $(0.0235)$ \\
\hline \multirow{3}{*}{ Observations } & & & \\
R-squared & 438 & 142 & 296 \\
Number of ifs_code & 0.299 & 0.478 & 0.285 \\
\hline
\end{tabular}

pval in parentheses

$* * * p<0.01, * * p<0.05, * p<0.1$

Panel B

\begin{tabular}{lcc|cc|cc}
\hline \hline & \multicolumn{2}{c|}{ NIG ratings } & \multicolumn{2}{c|}{ LIG ratings } & \multicolumn{2}{c}{ HIG ratings } \\
\hline & Full sample & EMDEs & Full sample & EMDEs & Full sample & AEs \\
\hline Net debt & $-0.0148^{* *}$ & $-0.0168^{* *}$ & $-0.0437^{* * *}$ & $-0.0536^{* * *}$ & $-0.0243^{* * *}$ & $-0.0247^{* * *}$ \\
& $(0.0257)$ & $(0.0129)$ & $(1.66 \mathrm{e}-05)$ & $(8.74 \mathrm{e}-06)$ & $(3.95 \mathrm{e}-06)$ & $(6.73 \mathrm{e}-06)$ \\
GDP growth & 0.00634 & -0.00309 & 0.0142 & 0.00954 & $0.0829^{*}$ & $0.0836^{*}$ \\
& $(0.837)$ & $(0.922)$ & $(0.454)$ & $(0.639)$ & $(0.0811)$ & $(0.0872)$ \\
Inflation & -0.00831 & -0.00751 & -0.0177 & -0.0245 & 0.0641 & 0.0777 \\
& $(0.461)$ & $(0.507)$ & $(0.451)$ & $(0.340)$ & $(0.361)$ & $(0.289)$ \\
VIX & 0.0102 & 0.0101 & $-0.0508^{* * *}$ & $-0.0595^{* * *}$ & 0.00716 & 0.00903 \\
& $(0.523)$ & $(0.532)$ & $(3.17 \mathrm{e}-05)$ & $(1.80 \mathrm{e}-05)$ & $(0.600)$ & $(0.537)$ \\
US interest rate & $0.360^{* *}$ & $0.340^{* *}$ & -0.0487 & -0.0785 & -0.0686 & -0.0775 \\
& $(0.0321)$ & $(0.0447)$ & $(0.608)$ & $(0.475)$ & $(0.519)$ & $(0.482)$ \\
GDP per capita & $3.192^{* * *}$ & $3.038^{* *}$ & $1.887^{* * *}$ & $1.714^{* *}$ & 0.511 & 0.408 \\
& $(0.00648)$ & $(0.0101)$ & $(0.00218)$ & $(0.0107)$ & $(0.704)$ & $(0.768)$ \\
Constant & $-19.00^{*}$ & -17.33 & -0.511 & 1.362 & 16.67 & 18.00 \\
& $(0.0864)$ & $(0.119)$ & $(0.935)$ & $(0.842)$ & $(0.251)$ & $(0.228)$ \\
\hline & & & & & & \\
Observations & 181 & 173 & 142 & 117 & 115 & 109 \\
R-squared & 0.172 & 0.179 & 0.447 & 0.486 & 0.320 & 0.316 \\
Number of ifs_code & 38 & 35 & 27 & 21 & 23 & 20 \\
\hline
\end{tabular}

pval in parentheses

*** $p<0.01, * * p<0.05, * p<0.1$ 


\begin{tabular}{|c|c|c|c|}
\hline \multicolumn{4}{|c|}{$\begin{array}{l}\text { Table 9. Panel Results for the Institutional } \\
\qquad \text { (Fixed effects; Net debt) } \\
\text { Panel A }\end{array}$} \\
\hline & \multicolumn{3}{|c|}{ Institutional Investor Index } \\
\hline & Full sample & AEs & EMDEs \\
\hline \multirow[t]{2}{*}{ Net debt } & $-0.125^{* * *}$ & $-0.175^{* * *}$ & $-0.0784 * * *$ \\
\hline & $(2.39 \mathrm{e}-09)$ & $(2.04 \mathrm{e}-06)$ & $(0.00136)$ \\
\hline \multirow[t]{2}{*}{ GDP growth } & $0.188^{* *}$ & $1.041 * * *$ & 0.110 \\
\hline & $(0.0324)$ & $(0.000263)$ & $(0.182)$ \\
\hline \multirow[t]{2}{*}{ Inflation } & -0.0175 & 0.174 & 0.00869 \\
\hline & $(0.718)$ & $(0.647)$ & $(0.837)$ \\
\hline \multirow[t]{2}{*}{ VIX } & $0.110^{* *}$ & $0.212 * *$ & 0.0801 \\
\hline & $(0.0203)$ & $(0.0377)$ & $(0.104)$ \\
\hline \multirow[t]{2}{*}{ US interest rate } & $2.059 * * *$ & $1.281^{*}$ & $0.747^{*}$ \\
\hline & $(1.46 \mathrm{e}-08)$ & $(0.0750)$ & $(0.0916)$ \\
\hline \multirow[t]{2}{*}{ GDP per capita } & $40.93 * * *$ & $28.36^{* * *}$ & $38.27^{* * *}$ \\
\hline & (0) & $(0.000784)$ & (0) \\
\hline \multirow[t]{2}{*}{ Constant } & $-345.0 * * *$ & $-222.8^{* *}$ & $-310.7^{* * *}$ \\
\hline & (0) & $(0.0128)$ & $(0)$ \\
\hline Observations & 434 & 142 & 292 \\
\hline R-squared & 0.544 & 0.491 & 0.652 \\
\hline Countries & 65 & 22 & 43 \\
\hline pval in parenth & & & \\
\hline$* * * p<0.01, * *$ & & & \\
\hline
\end{tabular}

Note: Dependent variable is the Institutional Investor Index of country sovereign risk.

Panel B

\begin{tabular}{lccc}
\hline \hline & \multicolumn{3}{c}{ Institutional Investor Index } \\
\hline & NIG ratings & LIG ratings & HIG ratings \\
\hline Net debt & -0.0323 & $-0.272^{* * *}$ & $-0.0570^{* *}$ \\
& $(0.255)$ & $(2.16 \mathrm{e}-05)$ & $(0.0219)$ \\
GDP growth & -0.0342 & 0.161 & 0.181 \\
& $(0.766)$ & $(0.181)$ & $(0.439)$ \\
Inflation & 0.0102 & -0.203 & 0.264 \\
& $(0.839)$ & $(0.172)$ & $(0.447)$ \\
VIX & $0.121^{* *}$ & 0.0353 & 0.0729 \\
& $(0.0496)$ & $(0.633)$ & $(0.283)$ \\
US interest rate & $2.287^{* * *}$ & 0.538 & $1.754^{* * *}$ \\
& $(0.000404)$ & $(0.370)$ & $(0.00125)$ \\
GDP per capita & $42.95^{* * *}$ & $35.71^{* * *}$ & $43.96^{* * *}$ \\
& $(0)$ & $(0)$ & $(3.28 \mathrm{e}-09)$ \\
Constant & $-357.2^{* * *}$ & $-287.7^{* * *}$ & $-385.9 * * *$ \\
& $(0)$ & $(6.16 \mathrm{e}-11)$ & $(5.92 \mathrm{e}-07)$ \\
\hline Observations & 174 & 142 & 115 \\
R-squared & 0.578 & 0.645 & 0.533 \\
Countries & 38 & 27 & 23 \\
\hline \hline pval in parentheses & \multicolumn{3}{c}{} \\
$* * *$ p $<0.01, * * p<0.05, * 0.1$ & & \\
\hline
\end{tabular}

Note: Dependent variable is the Institutional Investor Index of country sovereign risk. 


\section{B. Controlling for Diversification}

The findings are also very robust to inclusion of a diversification indicator. Table 10 shows that the results from ordered probit and panel regressions remain virtually unchanged, even though higher export diversification is found to be associated with better credit ratings in several specifications. ${ }^{10}$

\section{Lagged Dependent Variable}

The key findings of the analysis are robust to the inclusion of a lagged dependent variable. Table 11 indicates that the main estimation result - the negative impact of public debt on credit ratings - holds notwithstanding the strong persistence of the ratings variables. Panel A shows that all ordered probit specifications retain the negative coefficient from the baseline, and all except one specification are strongly significant. Panels B and C draw a similar conclusion for the panel regressions with gross and net debt, respectively. ${ }^{11}$

\section{Alternative Rating Groupings}

Table 12 shows that the main results from Tables 3 and 4 are robust to alternative ratings groupings. Instead of the rating groups presented in Table 1, the specifications are based on two alternatives. First, we check the robustness to a slightly different breakdown for HIG and LIG, moving A+ from the first to the second group in order to keep together all A grades. The top two panels of Table 12 (for probit and standard panel regressions respectively) show that the middle group (LIG) still has the highest effect, while the HIG and NIG groups tend to experience lower effects.

Second, we employ a four-category breakdowns, which allows us to zoom-in in the lowest category (NIG) and separate it into two groups, with all "B-BBB" grades placed in High Non-Investment Grade (HNIG) category, and all grades below "B-" placed in Low NonInvestment Grade (LNIG) category. Unfortunately, the limited size of the lowest category (LNIG) prevents the ability to run the probit and suggests that results from standard panel regressions should be mainly considered as indicative. Nonetheless, the results shown in the bottom Panel (C) of Table 12 are very much in line with our nonlinear relation identified earlier with the more nuanced rolling regressions: the effect for NIG is weaker at the lower end (LNIG), and stronger at the higher end (HNIG).

\footnotetext{
${ }^{10}$ Similarly, the results for specifications with the Institutional Investor Index and various country sub-groups are also very robust to the inclusion of diversification controls. Results are available upon request.

${ }^{11}$ The specifications that include the Institutional Investor Index and various sub-groups of countries lead to similar conclusions about the robustness of the key relationships. The results are available upon request.
} 
Table 10. Ordered Probit and Panel Regression Results with Diversification Panel A: Ordered probit

\begin{tabular}{|c|c|c|c|c|c|c|}
\hline & Rating category & Rating category & Rating category & Rating category & Rating category & Rating category \\
\hline & Full sample & Advanced economies & EMDEs & Full sample & Advanced economies & EMDEs \\
\hline \multirow[t]{2}{*}{ Gross debt } & $-0.0682 * * *$ & $-0.0574 * * *$ & $-0.0712 * * *$ & & & \\
\hline & (0) & $(8.09 \mathrm{e}-05)$ & $(4.97 e-05)$ & & & \\
\hline \multirow[t]{2}{*}{ Net debt } & & & & $-0.115 * * *$ & $-0.116 * * *$ & $-0.119 * * *$ \\
\hline & & & & (1.58e-08) & $(0.00856)$ & $(0.000366)$ \\
\hline \multirow[t]{2}{*}{ GDP growth } & $0.0443 *$ & 0.0505 & 0.0263 & 0.0426 & -0.0485 & 0.0194 \\
\hline & $(0.0765)$ & $(0.435)$ & (0.388) & $(0.203)$ & (0.688) & (0.636) \\
\hline \multirow[t]{2}{*}{ Inflation } & $-0.0743^{* *}$ & -0.0885 & -0.0604 & $-0.134^{* * *}$ & -0.0811 & -0.102 \\
\hline & $(0.0183)$ & $(0.246)$ & (0.162) & $(0.00373)$ & $(0.602)$ & (0.114) \\
\hline \multirow[t]{2}{*}{ VIX } & 0.0188 & 0.00373 & 0.0165 & 0.0221 & -0.0484 & 0.0256 \\
\hline & $(0.241)$ & $(0.890)$ & $(0.476)$ & $(0.334)$ & $(0.416)$ & $(0.446)$ \\
\hline \multirow[t]{2}{*}{ US interest rate } & 0.198 & $0.448^{*}$ & 0.0955 & $0.301^{*}$ & $1.068^{* *}$ & -0.265 \\
\hline & (0.106) & $(0.0545)$ & (0.619) & $(0.0505)$ & $(0.0235)$ & (0.335) \\
\hline \multirow[t]{2}{*}{ GDP per capita } & $4.475 * * *$ & $8.255^{* * *}$ & $4.144^{* * *}$ & $3.391^{* * *}$ & 6.905 & 2.645 \\
\hline & $(2.88 \mathrm{e}-07)$ & (5.36e-05) & $(0.00135)$ & $(0.00669)$ & $(0.113)$ & (0.143) \\
\hline \multirow[t]{2}{*}{ Diversification } & $5.089^{*}$ & -4.162 & $8.080^{*}$ & -4.202 & -13.59 & 3.340 \\
\hline & $(0.0585)$ & $(0.405)$ & $(0.0576)$ & $(0.253)$ & $(0.148)$ & $(0.611)$ \\
\hline Observations & 683 & 203 & 480 & 415 & 131 & 284 \\
\hline
\end{tabular}

Panel B: Gross debt panel regressions

\begin{tabular}{|c|c|c|c|c|c|c|c|c|c|c|}
\hline & \multicolumn{3}{|c|}{ All ratings } & \multicolumn{2}{|c|}{ NIG ratings } & \multicolumn{3}{|c|}{ LIG ratings } & \multicolumn{2}{|c|}{ HIG ratings } \\
\hline & Full sample & AEs & EMDES & Full sample & EMDEs & Full sample & AEs & EMDES & Full sample & AEs \\
\hline \multirow[t]{2}{*}{ Gross debt } & $-0.0368^{* * *}$ & $-0.0516^{* * *}$ & $-0.0223 * * *$ & $-0.0124^{* *}$ & $-0.0114^{* *}$ & $-0.0360^{* * *}$ & $-0.0396 * * *$ & $-0.0396 * * *$ & $-0.0244^{* * *}$ & $-0.0240 * * *$ \\
\hline & (0) & $(2.65 e-09)$ & $(2.11 e-07)$ & $(0.0194)$ & $(0.0294)$ & (3.46e-07) & (0.00991) & $(2.12 \mathrm{e}-06)$ & $(1.40 \mathrm{e}-07)$ & $(6.00 e-07)$ \\
\hline \multirow[t]{2}{*}{ GDP growth } & $0.0482^{* * *}$ & $0.244^{* * *}$ & 0.00980 & -0.0206 & -0.0153 & $0.0306 *$ & 0.0451 & 0.0107 & $0.0675^{*}$ & 0.0601 \\
\hline & $(0.00612)$ & $(2.63 e-05)$ & (0.519) & $(0.341)$ & (0.476) & $(0.0956)$ & (0.551) & (0.547) & $(0.0712)$ & $(0.137)$ \\
\hline \multirow[t]{2}{*}{ Inflation } & $-0.0338^{* * *}$ & -0.0966 & $-0.0284 * * *$ & $-0.0205 *$ & $-0.0212^{*}$ & 0.00212 & -0.0116 & 0.0111 & 0.0254 & 0.00938 \\
\hline & $(0.00697)$ & $(0.212)$ & (0.00491) & $(0.0663)$ & $(0.0528)$ & $(0.920)$ & (0.859) & (0.605) & (0.606) & $(0.876)$ \\
\hline \multirow[t]{2}{*}{ VIX } & 0.000126 & 0.0197 & $-0.0165 *$ & -0.0119 & -0.0105 & $-0.0294 * * *$ & 0.00926 & $-0.0454^{* * *}$ & -0.00318 & -0.00421 \\
\hline & $(0.990)$ & (0.413) & $(0.0797)$ & $(0.331)$ & $(0.383)$ & $(0.00434)$ & (0.696) & $(3.49 \mathrm{e}-05)$ & (0.793) & $(0.751)$ \\
\hline \multirow[t]{2}{*}{ US interest rate } & $0.305^{* * *}$ & $0.325^{*}$ & 0.0885 & $0.208^{*}$ & $0.247^{* *}$ & -0.0696 & 0.0239 & -0.0761 & -0.0812 & -0.0520 \\
\hline & (5.07e-05) & $(0.0763)$ & $(0.247)$ & $(0.0535)$ & $(0.0210)$ & $(0.425)$ & (0.918) & (0.398) & $(0.392)$ & $(0.616)$ \\
\hline \multirow[t]{2}{*}{ GDP per capita } & $4.121^{* * *}$ & $7.918^{* * *}$ & $3.014^{* * *}$ & $3.224 * * *$ & $3.451 * * *$ & $2.230 * * *$ & $6.473^{* * *}$ & $1.626 * * *$ & 1.038 & 1.244 \\
\hline & (0) & $(1.43 e-05)$ & $(1.96 e-10)$ & $(7.05 e-05)$ & $(1.79 e-05)$ & $(5.93 e-05)$ & $(0.00116)$ & $(0.00321)$ & $(0.286)$ & $(0.256)$ \\
\hline \multirow[t]{2}{*}{ Diversification } & 0.429 & -4.166 & 0.805 & -0.303 & -0.370 & $3.520^{*}$ & 11.43 & 1.803 & -2.001 & -2.839 \\
\hline & (0.715) & $(0.389)$ & (0.411) & $(0.784)$ & $(0.732)$ & (0.0788) & $(0.101)$ & $(0.361)$ & $(0.456)$ & $(0.328)$ \\
\hline \multirow[t]{2}{*}{ Constant } & $-24.23 * * *$ & $-60.29 * * *$ & $-14.24 * * *$ & $-17.82^{* *}$ & $-19.90 * * *$ & -4.751 & $-50.22 * *$ & 1.816 & 12.58 & 10.76 \\
\hline & $(4.61 \mathrm{e}-06)$ & $(0.00127)$ & $(0.00166)$ & $(0.0180)$ & $(0.00728)$ & $(0.399)$ & $(0.0127)$ & $(0.744)$ & $(0.221)$ & $(0.351)$ \\
\hline Observations & 683 & 203 & 480 & 304 & 290 & 231 & 53 & 178 & 148 & 136 \\
\hline R-squared & 0.350 & 0.548 & 0.313 & 0.173 & 0.191 & 0.377 & 0.605 & 0.392 & 0.332 & 0.315 \\
\hline Countries & 103 & 31 & 72 & 68 & 62 & 45 & 12 & 33 & 35 & 30 \\
\hline
\end{tabular}

Panel C: Net debt panel regressions

\begin{tabular}{|c|c|c|c|c|c|c|c|c|c|}
\hline & \multicolumn{3}{|c|}{ All ratings } & \multicolumn{2}{|c|}{ NIG ratings } & \multicolumn{2}{|c|}{ LIG ratings } & \multicolumn{2}{|c|}{ HIG ratings } \\
\hline & Full sample & AEs & EMDEs & Full sample & EMDES & Full sample & EMDES & Full sample & $\mathrm{AES}$ \\
\hline \multirow[t]{2}{*}{ Net debt } & $-0.0285^{* * *}$ & $-0.0464^{* * *}$ & $-0.0174^{* * *}$ & -0.0106 & $-0.0117^{*}$ & $-0.0465 * * *$ & $-0.0539 * * *$ & $-0.0203^{* * *}$ & $-0.0207^{* * *}$ \\
\hline & $(2.13 e-08)$ & $(1.34 \mathrm{e}-06)$ & $(0.00165)$ & $(0.128)$ & $(0.0993)$ & $(2.32 \mathrm{e}-05)$ & $(2.21 \mathrm{e}-05)$ & $(0.000257)$ & $(0.000333)$ \\
\hline \multirow[t]{2}{*}{ GDP growth } & $0.0456 * *$ & $0.260 * * *$ & 0.0215 & -0.0142 & -0.0175 & 0.00514 & 0.00444 & 0.0827 & 0.0809 \\
\hline & $(0.0377)$ & $(0.000448)$ & $(0.290)$ & (0.654) & $(0.587)$ & $(0.789)$ & $(0.828)$ & (0.108) & (0.129) \\
\hline \multirow[t]{2}{*}{ Inflation } & -0.0139 & -0.119 & -0.00508 & -0.00887 & -0.00830 & -0.00354 & -0.0120 & 0.0930 & 0.104 \\
\hline & $(0.243)$ & $(0.255)$ & $(0.622)$ & $(0.435)$ & $(0.468)$ & (0.881) & $(0.642)$ & (0.219) & (0.189) \\
\hline \multirow[t]{2}{*}{ VIX } & -0.00349 & 0.0413 & -0.0154 & 0.00224 & 0.00264 & $-0.0505^{* * *}$ & $-0.0583 * * *$ & -0.000982 & 0.000951 \\
\hline & (0.771) & (0.112) & $(0.206)$ & (0.891) & $(0.873)$ & $(4.00 e-05)$ & $(2.58 \mathrm{e}-05)$ & (0.947) & (0.952) \\
\hline \multirow[t]{2}{*}{ US interest rate } & $0.334^{* * *}$ & 0.174 & 0.0497 & $0.351^{* *}$ & $0.343^{* *}$ & -0.0865 & -0.103 & -0.0949 & -0.0966 \\
\hline & $(0.000225)$ & $(0.382)$ & (0.645) & $(0.0364)$ & $(0.0425)$ & (0.369) & $(0.345)$ & $(0.433)$ & (0.449) \\
\hline \multirow[t]{2}{*}{ GDP per capita } & $3.564 * * *$ & 0.696 & $3.337 * * *$ & $3.708 * * *$ & $3.638 * * *$ & $1.549 * *$ & $1.468^{* *}$ & 0.640 & 0.602 \\
\hline & $(1.84 \mathrm{e}-06)$ & $(0.775)$ & $(6.25 e-06)$ & $(0.00286)$ & $(0.00365)$ & $(0.0126)$ & $(0.0285)$ & (0.666) & (0.696) \\
\hline \multirow[t]{2}{*}{ Diversification } & 0.497 & -6.927 & $2.630 *$ & 0.482 & 0.501 & $4.807^{*}$ & 4.589 & 1.873 & 1.573 \\
\hline & (0.744) & $(0.205)$ & $(0.0605)$ & $(0.762)$ & $(0.754)$ & $(0.0712)$ & (0.102) & (0.583) & $(0.660)$ \\
\hline \multirow[t]{2}{*}{ Constant } & $-19.81^{* * *}$ & 15.03 & $-18.38^{* *}$ & $-23.64 * *$ & $-22.82^{*}$ & 1.672 & 2.601 & 14.85 & 15.59 \\
\hline & $(0.00806)$ & (0.554) & $(0.0106)$ & $(0.0440)$ & $(0.0522)$ & $(0.796)$ & $(0.707)$ & $(0.341)$ & $(0.337)$ \\
\hline Observations & 415 & 131 & 284 & 170 & 164 & 135 & 114 & 110 & 104 \\
\hline R-squared & 0.272 & 0.459 & 0.291 & 0.162 & 0.166 & 0.476 & 0.510 & 0.281 & 0.275 \\
\hline Countries & 64 & 22 & 42 & 37 & 34 & 27 & 21 & 23 & 20 \\
\hline
\end{tabular}

pval in parentheses

*** $p<0.01,{ }^{* *} p<0.05, * p<0.1$

Note: Dependent variable is the credit rating variable that assumes values from 1 (worst) to 23 (best). Diversification is measures by the export diversification indicator from Ding and Hadzi-Vaskov (2017). GDP per capita is PPP-adjusted. 
Table 11. Ordered Probit and Regression Results with Lagged Dependent Variable Panel A: Ordered probit

\begin{tabular}{|c|c|c|c|c|c|c|c|c|c|c|}
\hline & \multicolumn{2}{|c|}{ Rating category } & \multicolumn{2}{|c|}{ Rating category } & ing category & \multicolumn{2}{|c|}{ Rating category } & \multicolumn{2}{|c|}{ Rating category } & Rating category \\
\hline & \multicolumn{2}{|c|}{ Full sample } & \multicolumn{2}{|c|}{ Advanced economies } & EMDEs & \multicolumn{2}{|c|}{ Full sample } & \multicolumn{2}{|c|}{ Advanced economies } & EMDES \\
\hline \multirow[t]{2}{*}{ Gross debt } & \multicolumn{2}{|c|}{$-0.0480^{* * *}$} & \multicolumn{2}{|l|}{$-0.0432^{* *}$} & $-0.0628^{*}$ & & & & & \\
\hline & \multicolumn{2}{|c|}{$(0.000456)$} & \multicolumn{2}{|l|}{$(0.0415)$} & (0.0952) & & & & & \\
\hline \multirow[t]{2}{*}{ Net debt } & & & & & & \multicolumn{2}{|c|}{$-0.112^{* * *}$} & $-0.144^{*}$ & \multicolumn{2}{|c|}{-0.107} \\
\hline & & & & & & \multicolumn{2}{|c|}{$(0.00423)$} & (0.0673) & \multicolumn{2}{|c|}{$(0.180)$} \\
\hline \multirow[t]{2}{*}{ Rating category (Lagged) } & \multicolumn{2}{|c|}{$1.348^{* * *}$} & \multicolumn{2}{|l|}{$0.887^{* *}$} & $2.616^{* * *}$ & 1.726 & & 0.503 & & $106^{* *}$ \\
\hline & $(2.54$ & $e-05)$ & $(0.0384)$ & & $(0.00724)$ & $(0.001$ & & $(0.605)$ & & 0218) \\
\hline GDP growth & 0.10 & $6 * * *$ & $0.158^{*}$ & & $0.134^{* *}$ & 0.123 & & 0.223 & & $149^{*}$ \\
\hline & $(0.00$ & 417) & $(0.0971)$ & & $(0.0333)$ & $(0.01$ & & $(0.260)$ & & 0960) \\
\hline Inflation & -0.08 & $862^{*}$ & -0.0446 & & -0.0958 & -0.02 & & 0.333 & & 0237 \\
\hline & $(0.0$ & 676) & $(0.671)$ & & $(0.295)$ & $(0.74$ & & $(0.246)$ & & 851) \\
\hline VIX & 0.04 & $448^{*}$ & 0.0233 & & 0.0595 & 0.01 & & -0.107 & & 0579 \\
\hline & $(0.0$ & 725) & $(0.577)$ & & $(0.169)$ & $(0.60$ & & $(0.387)$ & & 282) \\
\hline US interest rate & 0.2 & 297 & 0.192 & & $0.972^{* *}$ & 0.19 & & 0.137 & & 0800 \\
\hline & $(0.1$ & 110) & (0.521) & & $(0.0390)$ & $(0.44$ & & $(0.805)$ & & 880) \\
\hline GDP per capita & 4.88 & $6 * * *$ & $6.476^{* *}$ & & $10.74^{* * *}$ & 1.67 & & -9.527 & & 567 \\
\hline & $(0.00$ & 0410) & $(0.0111)$ & & (0.00793) & $(0.39$ & & $(0.384)$ & & 266) \\
\hline Observations & 39 & 93 & 105 & & 288 & 244 & & 67 & & 177 \\
\hline & & & Panel B: & Gross d & ebt pane & 1 regressic & ons & & & \\
\hline & & All ratings & & NIG r & aatings & & LIG ratings & & HIG r & ings \\
\hline & ull sample & AEs & EMDES & Full sample & EMDES & Full sample & AEs & EMDES & Full sample & $\mathrm{AES}$ \\
\hline Gross debt & $-0.0259^{* * *}$ & $-0.0408^{* * *}$ & $-0.0192 * * *$ & $-0.0246^{* *}$ & $-0.0202^{* *}$ & $-0.0340^{* * *}$ & $-0.0442 * *$ & $-0.0262^{* *}$ & $-0.0173^{* *}$ & $-0.0160^{*}$ \\
\hline & $(6.48 \mathrm{e}-06)$ & $(0.00346)$ & $(0.000813)$ & $(0.0109)$ & $(0.0169)$ & $(0.000712)$ & $(0.0455)$ & $(0.0259)$ & $(0.0234)$ & $(0.0502)$ \\
\hline Rating (Lagged) & $0.563^{* * *}$ & $0.346^{* * *}$ & $0.624^{* * *}$ & $0.217^{* * *}$ & $0.523^{* * *}$ & $0.248^{* * *}$ & -0.0146 & $0.490^{* * *}$ & $0.533^{* *}$ & $0.539^{* *}$ \\
\hline & (0) & $(0.00115)$ & (0) & $(0.00244)$ & $(3.78 \mathrm{e}-10)$ & $(0.000316)$ & $(0.918)$ & $(3.24 \mathrm{e}-08)$ & $(0.0254)$ & $(0.0355)$ \\
\hline GDP growth & $0.0762 * * *$ & $0.207^{* *}$ & $0.0633^{* * *}$ & 0.0240 & $0.0516^{*}$ & 0.0334 & 0.0573 & $0.0403^{* *}$ & 0.0751 & 0.0427 \\
\hline & $(0.000110)$ & (0.0119) & (0.000144) & $(0.440)$ & $(0.0615)$ & (0.101) & (0.515) & (0.0334) & $(0.382)$ & $(0.682)$ \\
\hline Inflation & -0.0226 & -0.0282 & $-0.0229 *$ & -0.0157 & -0.0140 & -0.0135 & 0.0185 & -0.00749 & -0.0846 & -0.0939 \\
\hline & $(0.166)$ & $(0.804)$ & $(0.0745)$ & $(0.457)$ & $(0.436)$ & $(0.556)$ & $(0.810)$ & $(0.736)$ & $(0.482)$ & $(0.463)$ \\
\hline VIX & -0.0147 & 0.0186 & $-0.0234^{* *}$ & -0.0279 & -0.0285 & $-0.0486^{* * *}$ & -0.0395 & $-0.0477^{* * *}$ & 0.0378 & 0.0294 \\
\hline & $(0.255)$ & $(0.662)$ & $(0.0380)$ & $(0.175)$ & $(0.104)$ & $(0.000254)$ & $(0.292)$ & $(0.000498)$ & $(0.110)$ & $(0.295)$ \\
\hline US interest rate & $0.184^{*}$ & 0.265 & 0.0638 & 0.132 & 0.144 & 0.00633 & 0.0690 & -0.136 & 0.202 & 0.254 \\
\hline & (0.0713) & $(0.317)$ & $(0.532)$ & $(0.543)$ & $(0.443)$ & $(0.955)$ & $(0.820)$ & $(0.258)$ & $(0.290)$ & $(0.248)$ \\
\hline GDP per capita & $1.849^{* * *}$ & $5.907^{* *}$ & 0.929 & 1.249 & 1.150 & $1.301^{*}$ & 4.085 & -0.0434 & 0.957 & 1.640 \\
\hline & (0.00959) & $(0.0247)$ & $(0.139)$ & $(0.465)$ & $(0.435)$ & $(0.0656)$ & $(0.223)$ & $(0.952)$ & $(0.703)$ & $(0.570)$ \\
\hline Constant & -10.70 & $-48.08^{*}$ & -2.783 & -1.702 & -4.310 & 1.549 & -21.49 & 10.77 & -0.808 & -7.989 \\
\hline & $(0.128)$ & $(0.0759)$ & $(0.645)$ & $(0.916)$ & $(0.754)$ & $(0.825)$ & $(0.525)$ & $(0.123)$ & $(0.975)$ & (0.791) \\
\hline Observations & 393 & 105 & 288 & 189 & 175 & 146 & 39 & 107 & 58 & 52 \\
\hline R-squared & 0.629 & 0.696 & 0.601 & 0.235 & 0.436 & 0.538 & 0.541 & 0.643 & 0.697 & 0.690 \\
\hline Countries & 89 & 27 & 62 & 55 & 49 & 37 & 10 & 27 & 30 & 26 \\
\hline
\end{tabular}

Panel C: Net debt panel regressions

\begin{tabular}{|c|c|c|c|c|c|c|c|c|c|}
\hline & \multicolumn{3}{|c|}{ All ratings } & \multicolumn{2}{|c|}{ NIG ratings } & \multicolumn{2}{|c|}{ LIG ratings } & \multicolumn{2}{|c|}{ HIG ratings } \\
\hline & Full sample & AEs & EMDEs & Full sample & EMDES & Full sample & EMDES & Full sample & AEs \\
\hline \multirow[t]{2}{*}{ Net debt } & $-0.0216 * * *$ & -0.0123 & $-0.0279 * * *$ & $-0.0176 *$ & $-0.0213^{* *}$ & $-0.0225^{*}$ & $-0.0334 * *$ & $-0.0242^{*}$ & -0.0236 \\
\hline & $(0.000509)$ & $(0.338)$ & $(0.000115)$ & $(0.0828)$ & $(0.0412)$ & $(0.0863)$ & $(0.0141)$ & $(0.0701)$ & (0.109) \\
\hline & (0) & $(1.57 e-05)$ & (0) & $(1.31 e-05)$ & $(6.82 e-06)$ & $(0.00217)$ & $(2.02 \mathrm{e}-06)$ & (0.151) & (0.168) \\
\hline GDP growth & $0.0813^{* * *}$ & $0.204 * *$ & $0.0662 * * *$ & $0.0815^{* *}$ & $0.0729 *$ & 0.0290 & $0.0410 * *$ & 0.210 & 0.201 \\
\hline & $(0.321)$ & $(0.165)$ & $(0.863)$ & (0.914) & (0.993) & $(0.476)$ & $(0.160)$ & $(0.101)$ & (0.113) \\
\hline \multirow[t]{2}{*}{ VIX } & $-0.0244 *$ & 0.0215 & $-0.0314^{* *}$ & -0.0147 & -0.0147 & $-0.0570^{* * *}$ & $-0.0508 * * *$ & 0.0396 & 0.0378 \\
\hline & $(0.0686)$ & (0.559) & (0.0294) & (0.564) & $(0.562)$ & $(0.000263)$ & $(0.00125)$ & (0.142) & $(0.238)$ \\
\hline \multirow[t]{2}{*}{ US interest rate } & 0.166 & 0.219 & -0.0284 & 0.343 & 0.294 & 0.0587 & -0.0551 & -0.0830 & -0.0650 \\
\hline & $(0.121)$ & $(0.305)$ & $(0.841)$ & $(0.212)$ & $(0.284)$ & $(0.653)$ & $(0.703)$ & $(0.778)$ & $(0.850)$ \\
\hline Constant & $(0.365)$ & $(0.531)$ & $(0.925)$ & $(0.304)$ & $(0.389)$ & $(0.848)$ & $(0.539)$ & $(0.312)$ & $(0.411)$ \\
\hline Observations & 244 & 67 & 177 & 108 & 101 & 94 & 73 & 42 & 39 \\
\hline R-squared & 0.638 & 0.761 & 0.603 & 0.446 & 0.469 & 0.537 & 0.710 & 0.733 & 0.727 \\
\hline Countries & 55 & 20 & 35 & 29 & 26 & 23 & 18 & 20 & 18 \\
\hline
\end{tabular}

pval in parentheses

*** $p<0.01,{ }^{* *} p<0.05, * p<0.1$ 
Table 12. Ordered Probit and Regression Results with Alternative Ratings Groups

\begin{tabular}{|c|c|c|c|c|c|c|c|}
\hline \multicolumn{8}{|c|}{ Panel A: Ordered probit (all A grades in LIG) } \\
\hline & \multicolumn{2}{|c|}{ NIG ratings } & \multicolumn{3}{|c|}{ LIG ratings } & \multicolumn{2}{|c|}{ HIG ratings } \\
\hline & Full sample & EMDES & Full sample & AEs & EMDEs & Full sample & $\mathrm{AES}$ \\
\hline Gross debt & $\begin{array}{c}-0.0174^{* * *} \\
(0.000614)\end{array}$ & $\begin{array}{c}-0.0169 * * * \\
(0.00105)\end{array}$ & $\begin{array}{c}-0.0586^{* * *} \\
(7.55 e-10)\end{array}$ & $\begin{array}{c}-0.0470^{* * *} \\
(0.00435)\end{array}$ & $\begin{array}{c}-0.0856 * * * \\
(6.90 \mathrm{e}-09)\end{array}$ & $\begin{array}{c}-0.0322^{* * *} \\
(0.000305)\end{array}$ & $\begin{array}{c}-0.0321^{* * *} \\
(0.000317)\end{array}$ \\
\hline GDP growth & $\begin{array}{l}0.0160 \\
(0.435)\end{array}$ & $\begin{array}{l}0.0227 \\
(0.281)\end{array}$ & $\begin{array}{c}0.0887^{* * *} \\
(0.00119)\end{array}$ & $\begin{array}{c}0.142^{*} \\
(0.0810)\end{array}$ & $\begin{array}{l}0.0606^{*} \\
(0.0523)\end{array}$ & $\begin{array}{l}0.189^{* * *} \\
(0.00874)\end{array}$ & $\begin{array}{l}0.189 * * * \\
(0.00912)\end{array}$ \\
\hline Inflation & $\begin{array}{c}-0.0268^{* *} \\
(0.0128)\end{array}$ & $\begin{array}{c}-0.0288^{* * *} \\
(0.00790)\end{array}$ & $\begin{array}{l}0.000172 \\
(0.995)\end{array}$ & $\begin{array}{l}0.0193 \\
(0.816)\end{array}$ & $\begin{array}{l}0.0364 \\
(0.305)\end{array}$ & $\begin{array}{c}0.177 \\
(0.123)\end{array}$ & $\begin{array}{c}0.172 \\
(0.147)\end{array}$ \\
\hline VIX & $\begin{array}{l}0.00949 \\
(0.415)\end{array}$ & $\begin{array}{l}0.0115 \\
(0.326)\end{array}$ & $\begin{array}{l}-0.0278^{*} \\
(0.0579)\end{array}$ & $\begin{array}{l}0.0168 \\
(0.545)\end{array}$ & $\begin{array}{c}-0.0847^{* * *} \\
(1.67 \mathrm{e}-05)\end{array}$ & $\begin{array}{l}0.0122 \\
(0.627)\end{array}$ & $\begin{array}{l}0.0120 \\
(0.633)\end{array}$ \\
\hline US interest rate & $\begin{array}{l}0.270^{* *} \\
(0.0132)\end{array}$ & $\begin{array}{c}0.338^{* * *} \\
(0.00253)\end{array}$ & $\begin{array}{l}-0.178 \\
(0.161)\end{array}$ & $\begin{array}{c}0.256 \\
(0.349)\end{array}$ & $\begin{array}{l}-0.339 * * \\
(0.0318)\end{array}$ & $\begin{array}{l}-0.135 \\
(0.448)\end{array}$ & $\begin{array}{l}-0.135 \\
(0.449)\end{array}$ \\
\hline GDP per capita & $\begin{array}{c}3.432^{* * *} \\
(5.22 \mathrm{e}-05) \\
\end{array}$ & $\begin{array}{c}3.973^{* * *} \\
(7.26 \mathrm{e}-06) \\
\end{array}$ & $\begin{array}{c}4.544^{* * *} \\
(7.91 \mathrm{e}-09) \\
\end{array}$ & $\begin{array}{c}13.88^{* * *} \\
(1.40 \mathrm{e}-08) \\
\end{array}$ & $\begin{array}{c}3.533^{* * *} \\
(6.92 \mathrm{e}-05) \\
\end{array}$ & $\begin{array}{c}3.035 \\
(0.178) \\
\end{array}$ & $\begin{array}{c}3.004 \\
(0.183) \\
\end{array}$ \\
\hline $\begin{array}{l}\text { Observations } \\
\text { Countries }\end{array}$ & $\begin{array}{l}323 \\
71 \\
\end{array}$ & $\begin{array}{c}306 \\
65 \\
\end{array}$ & $\begin{array}{l}265 \\
47 \\
\end{array}$ & $\begin{array}{l}75 \\
14 \\
\end{array}$ & $\begin{array}{c}190 \\
33 \\
\end{array}$ & $\begin{array}{l}128 \\
28 \\
\end{array}$ & $\begin{array}{l}124 \\
26 \\
\end{array}$ \\
\hline \multicolumn{8}{|c|}{ Panel B: Panel regressions (all A grades in LIG) } \\
\hline & \multicolumn{2}{|c|}{ NIG ratings } & \multicolumn{3}{|c|}{ LIG ratings } & \multicolumn{2}{|c|}{ HIG ratings } \\
\hline & Full sample & EMDEs & Full sample & AEs & EMDEs & Full sample & AEs \\
\hline Gross debt & $\begin{array}{c}-0.0153^{* * *} \\
(0.00365)\end{array}$ & $\begin{array}{c}-0.0147^{* * *} \\
(0.00487)\end{array}$ & $\begin{array}{c}-0.0366 * * * \\
(6.14 \mathrm{e}-08)\end{array}$ & $\begin{array}{c}-0.0355^{* * *} \\
(0.00752)\end{array}$ & $\begin{array}{c}-0.0370^{* * *} \\
(5.75 \mathrm{e}-07)\end{array}$ & $\begin{array}{l}-0.0199 * * * \\
(3.44 \mathrm{e}-05)\end{array}$ & $\begin{array}{c}-0.0198^{* * *} \\
(4.43 \mathrm{e}-05)\end{array}$ \\
\hline GDP growth & $\begin{array}{l}0.00303 \\
(0.887)\end{array}$ & $\begin{array}{c}0.00449 \\
(0.833)\end{array}$ & $\begin{array}{l}0.0557^{* * *} \\
(0.00447)\end{array}$ & $\begin{array}{c}0.108^{*} \\
(0.0945)\end{array}$ & $\begin{array}{l}0.0235 \\
(0.172)\end{array}$ & $\begin{array}{l}0.0899 * * \\
(0.0148)\end{array}$ & $\begin{array}{c}0.0890 * * \\
(0.0205)\end{array}$ \\
\hline Inflation & $\begin{array}{c}-0.0218^{*} \\
(0.0568)\end{array}$ & $\begin{array}{c}-0.0224^{* *} \\
(0.0459)\end{array}$ & $\begin{array}{l}-0.0187 \\
(0.398)\end{array}$ & $\begin{array}{c}-0.00225 \\
(0.973)\end{array}$ & $\begin{array}{l}0.00368 \\
(0.855)\end{array}$ & $\begin{array}{l}0.0644 \\
(0.220)\end{array}$ & $\begin{array}{l}0.0760 \\
(0.213)\end{array}$ \\
\hline VIX & $\begin{array}{c}-0.000931 \\
(0.939)\end{array}$ & $\begin{array}{c}0.000545 \\
(0.964)\end{array}$ & $\begin{array}{l}-0.0162 \\
(0.129)\end{array}$ & $\begin{array}{l}0.00852 \\
(0.695)\end{array}$ & $\begin{array}{c}-0.0413^{* * *} \\
(0.000106)\end{array}$ & $\begin{array}{l}0.00331 \\
(0.784)\end{array}$ & $\begin{array}{l}0.00486 \\
(0.705)\end{array}$ \\
\hline US interest rate & $\begin{array}{l}0.229 * * \\
(0.0372)\end{array}$ & $\begin{array}{l}0.270^{* *} \\
(0.0133)\end{array}$ & $\begin{array}{l}-0.0608 \\
(0.500)\end{array}$ & $\begin{array}{c}0.174 \\
(0.422)\end{array}$ & $\begin{array}{l}-0.0918 \\
(0.278)\end{array}$ & $\begin{array}{l}-0.144 \\
(0.125)\end{array}$ & $\begin{array}{l}-0.145 \\
(0.126)\end{array}$ \\
\hline GDP per capita & $\begin{array}{c}2.748^{* * *} \\
(0.000586)\end{array}$ & $\begin{array}{c}2.993 * * * \\
(0.000158)\end{array}$ & $\begin{array}{c}2.916^{* * *} \\
(2.63 \mathrm{e}-08)\end{array}$ & $\begin{array}{c}9.850^{* * *} \\
(3.86 \mathrm{e}-08)\end{array}$ & $\begin{array}{c}1.818^{* * *} \\
(9.72 \mathrm{e}-05)\end{array}$ & $\begin{array}{c}0.512 \\
(0.617)\end{array}$ & $\begin{array}{c}0.489 \\
(0.640)\end{array}$ \\
\hline Constant & $\begin{array}{l}-14.00^{*} \\
(0.0612) \\
\end{array}$ & $\begin{array}{l}-16.26^{* *} \\
(0.0269) \\
\end{array}$ & $\begin{array}{l}-10.49 * * \\
(0.0487) \\
\end{array}$ & $\begin{array}{l}-82.41^{* * *} \\
(6.16 \mathrm{e}-06) \\
\end{array}$ & $\begin{array}{c}0.449 \\
(0.924) \\
\end{array}$ & $\begin{array}{c}17.73 \\
(0.114) \\
\end{array}$ & $\begin{array}{c}18.02 \\
(0.114) \\
\end{array}$ \\
\hline Observations & 323 & 306 & 265 & 75 & 190 & 128 & 124 \\
\hline R-squared & 0.162 & 0.182 & 0.389 & 0.651 & 0.417 & 0.307 & 0.303 \\
\hline Countries & 71 & 65 & 47 & 14 & 33 & 28 & 26 \\
\hline
\end{tabular}

Panel C: Panel regressions (all B-BBB grades in HNIG; grades below B- in LNIG)

\begin{tabular}{lcccc|ccc|cc}
\hline & \multicolumn{2}{c}{ LNIG ratings } & \multicolumn{2}{c|}{ HNIG ratings } & \multicolumn{3}{c|}{ LIG ratings } & HIG ratings \\
\hline & Full sample & EMDEs & Full sample & EMDEs & Full sample & AEs & EMDEs & Full sample & AEs \\
\hline Gross debt & 0.00168 & -0.0738 & $-0.0211^{* * *}$ & $-0.0196^{* * *}$ & $-0.0366^{* * *}$ & $-0.0355^{* * *}$ & $-0.0370^{* * *}$ & $-0.0199^{* * *}$ & $-0.0198^{* * *}$ \\
& $(0.978)$ & $(0.539)$ & $(1.10 \mathrm{e}-05)$ & $(2.68 \mathrm{e}-05)$ & $(6.14 \mathrm{e}-08)$ & $(0.00752)$ & $(5.75 \mathrm{e}-07)$ & $(3.44 \mathrm{e}-05)$ & $(4.43 \mathrm{e}-05)$ \\
& -0.312 & -0.178 & -0.000676 & 0.00719 & $0.0557^{* * *}$ & $0.108^{*}$ & 0.0235 & $0.0899^{* *}$ & $0.0890^{* *}$ \\
GDP growth & $(0.228)$ & $(0.559)$ & $(0.969)$ & $(0.678)$ & $(0.00447)$ & $(0.0945)$ & $(0.172)$ & $(0.0148)$ & $(0.0205)$ \\
& -0.101 & -0.199 & $-0.0273^{* * *}$ & $-0.0288^{* * *}$ & -0.0187 & -0.00225 & 0.00368 & 0.0644 & 0.0760 \\
Inflation & $(0.552)$ & $(0.401)$ & $(0.00473)$ & $(0.00212)$ & $(0.398)$ & $(0.973)$ & $(0.855)$ & $(0.220)$ & $(0.213)$ \\
& -0.00767 & 0.0241 & 0.00205 & 0.00306 & -0.0162 & 0.00852 & $-0.0413^{* * *}$ & 0.00331 & 0.00486 \\
VIX & $(0.917)$ & $(0.785)$ & $(0.842)$ & $(0.760)$ & $(0.129)$ & $(0.695)$ & $(0.000106)$ & $(0.784)$ & $(0.705)$ \\
& 0.0248 & -0.0466 & 0.138 & $0.171^{* *}$ & -0.0608 & 0.174 & -0.0918 & -0.144 & -0.145 \\
US interest rate & $(0.980)$ & $(0.965)$ & $(0.122)$ & $(0.0484)$ & $(0.500)$ & $(0.422)$ & $(0.278)$ & $(0.125)$ & $(0.126)$ \\
& -17.40 & -34.07 & $2.177^{* * *}$ & $2.356 * * *$ & $2.916 * * *$ & $9.850^{* * *}$ & $1.818^{* * *}$ & 0.512 & 0.489 \\
GDP per capita & $(0.205)$ & $(0.249)$ & $(0.000925)$ & $(0.000228)$ & $(2.63 \mathrm{e}-08)$ & $(3.86 \mathrm{e}-08)$ & $(9.72 \mathrm{e}-05)$ & $(0.617)$ & $(0.640)$ \\
& 156.7 & 300.4 & -8.047 & $-9.822^{*}$ & $-10.49 * *$ & $-82.41^{* * *}$ & 0.449 & 17.73 & 18.02 \\
Constant & $(0.199)$ & $(0.246)$ & $(0.191)$ & $(0.0980)$ & $(0.0487)$ & $(6.16 \mathrm{e}-06)$ & $(0.924)$ & $(0.114)$ & $(0.114)$ \\
& 19 & 17 & 304 & 289 & 265 & 75 & 190 & 128 & 124 \\
\hline Observations & 0.784 & 0.848 & 0.260 & 0.285 & 0.389 & 0.651 & 0.417 & 0.307 & 0.303 \\
R-squared & 10 & 9 & 71 & 65 & 47 & 14 & 33 & 28 \\
Countries & & & & & & & 26 \\
\hline \hline
\end{tabular}

pval in parentheses

*** $p<0.01,{ }^{* *} p<0.05, * p<0.1$ 


\section{E. Ordered Logit}

Results are also robust to the choice of ordered probit instead of ordered logit. Figure 10 presents the coefficient estimated from ordered logit rolling regressions, and Figure 11 shows the implies marginal probabilities based on 5-grade window rolling regressions that use logit instead of probit form. Similar as the ordered probit findings, Figures 10 and 11 suggests a highly non-linear pattern - public debt's negative impact is particularly severe for the middle area, and within each 5-grade window there is much higher probability of falling in the lower grades (grade 1 or 2 ) for credit grades in the middle than in the extremes of the credit rating distribution. The marginal effects from the logit estimation are consistent with the probit results and suggest that a debt increase of 10 percent of GDP would lower the probability of being placed in the better grades (within the 5-grade windows) by about 5 percent for the middle range of the ratings group, with the effect being smaller for the grades toward the extremes of the ratings distribution.

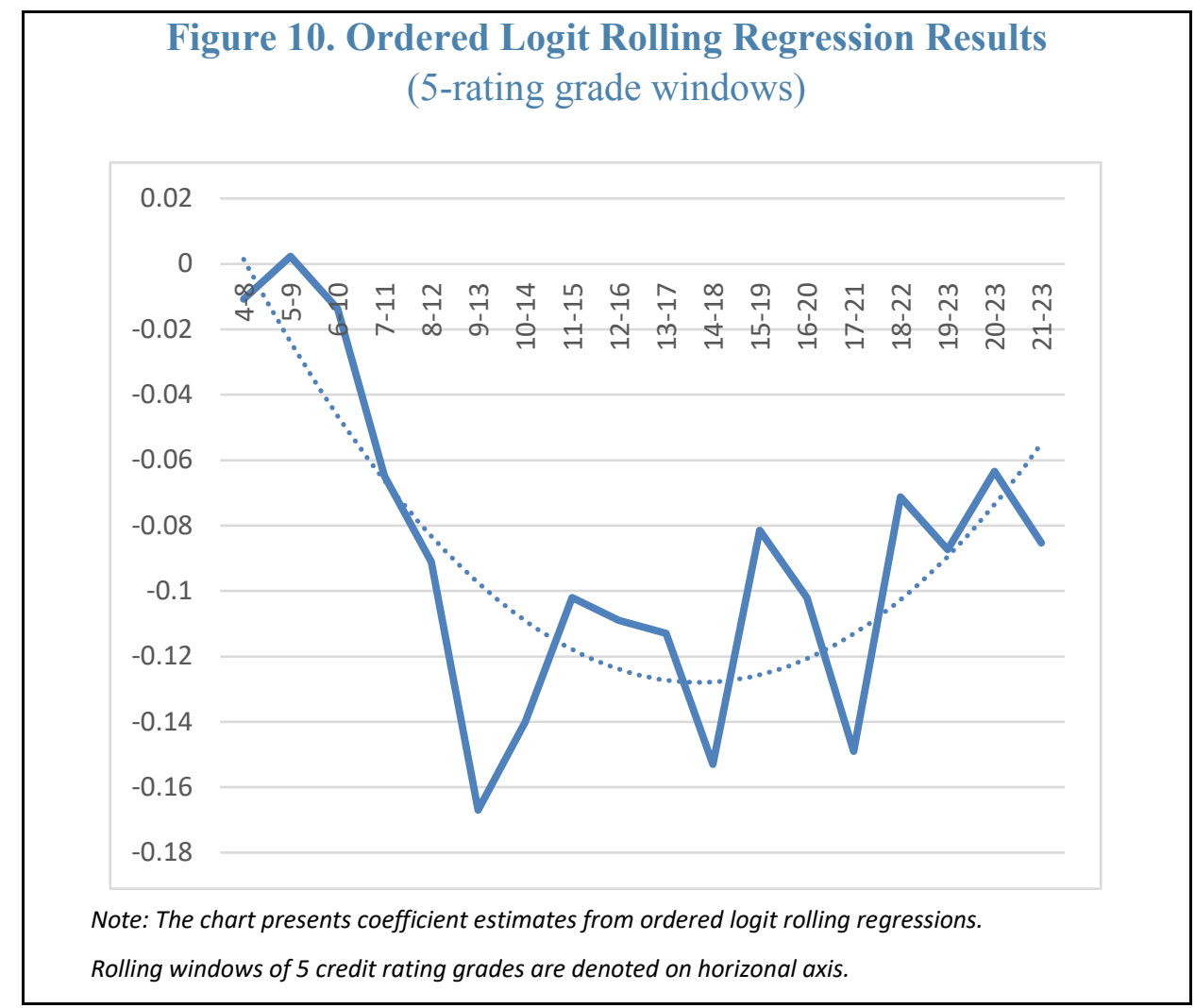




\section{Figure 11. Marginal Probabilities from Ordered Logit Rolling Regressions (5-rating grade windows)}
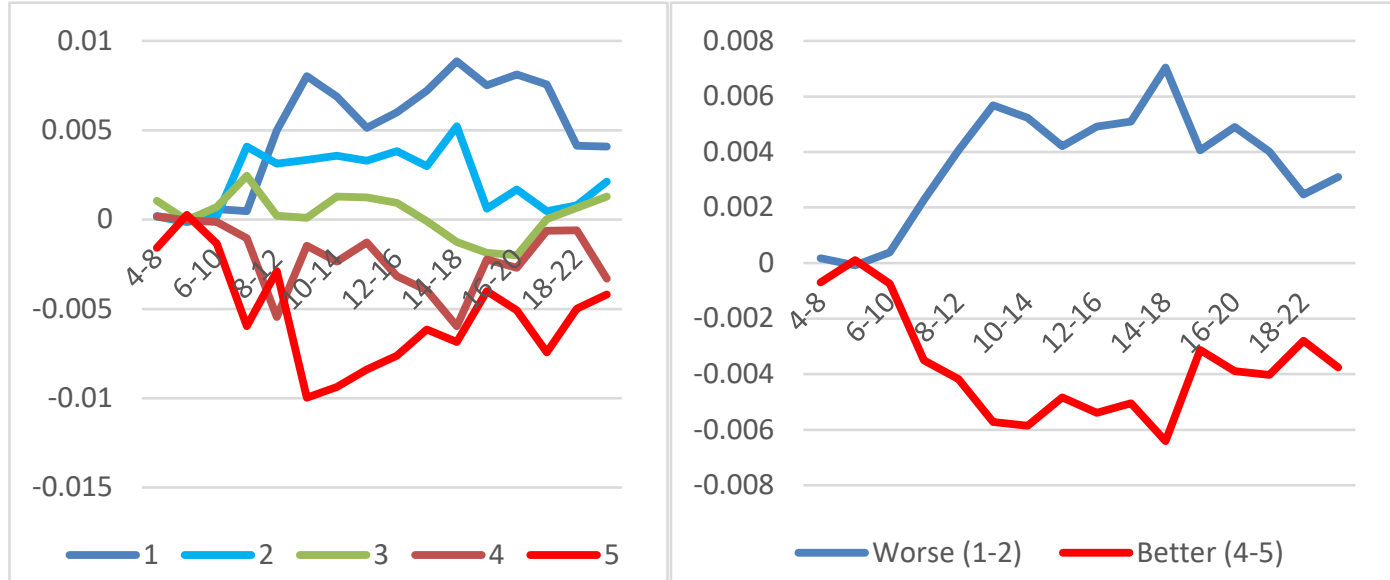

Note: The lines depict the marginal probabilities of being placed in different grades within the 5-grade windows, with the line marked by 1 corresponding to the lowest rating grade and the line marked by 5 to the best rating grade within the 5-grade window. In the right chart, the lines "Worse" ("Better") correspond to the average of lines 1 and 2 (4 and 5) in the left chart.

\section{CONCLUding Remarks}

The analysis has focused on investigating the relationship between public debt and sovereign credit ratings employing a wide range of analytical techniques, specifications, and country groupings. It offers three main conclusions.

First, the results from the ordered probit analysis confirm that higher public debt lowers the probability of being placed in a better credit rating category. This result holds when public debt is measured in gross and in net terms and applies to both AEs and EMDEs.

Second, the negative relation between debt and ratings is nonlinear and depends on the rating grade itself. The effect is strongest in the middle range of rating grades (broadly encompassing the low investment grades), is smallest at the lower end of the ratings range (non-investment grades), and is of intermediate size for the upper end of the ratings range (high investment grades).

Third, the above nonlinear relation - coupled with the uneven distribution of AEs and EMDEs across rating grades - explains the apparent difference in the effect of debt on ratings for AEs and EMDEs even when controlling for income level and a set of macroeconomic variables. Indeed, in the middle range of rating grades (lower range of the investment grade), where we have adequate data availability for both AEs and EMDEs, we find that the negative effect of debt on ratings is very similar for the two groups of countries. Moreover, the findings that the effect is smaller for countries that have a high rating grade 
(higher range of investment grades, which applies mainly to AEs), and smallest for countries that have a low rating grades (non-investment grade, which applies mainly to EMDEs), coupled with the difference in the distribution of AEs and EMDEs across the nonlinear debtcredit ratings relation, explain why the impact in AEs seems to be larger than in EMDEs.

A deeper understanding of the underlying reasons leading to the identified nonlinearity is an interesting issue that is left for future research. We speculate that the revealed nonlinearity might be due to the quality of institutions and policy credibility. Most of the action happens for countries in the middle range of the rating scale (the lower half of investment grade), where current debt is an important indicator of the health of public finances. Countries with the best credit ratings, instead, are perceived as most creditworthy and enjoy the strongest institutional frameworks more broadly-hence, an increase in debt is not likely to have a strong effect on ratings, as the market expect such an increase to be offset in the future, which can explain a more limited negative impact of debt on ratings. On the other extreme, the weakest grades suffer from a multitude of deficiencies, including lack of policy credibility and adequate institutions, which could be more important for determining their ratings than debt. Some exceptions to the patterns identified in this paper are visible in the charts in the introduction, but there are good reasons for them: for example some AEs enjoy very high credit ratings despite also having high debt levels as they are considered safe heavens, while some developing economies have both low debt levels and low credit ratings as they have limited access to market.

In terms of quantifying the effects, our results from the ordered probit and logit regressions suggest that for countries with middle ratings (LIG group) a debt increase by 10 percent of GDP is associated with about 5 percent higher (lower) probability of being placed into a worse (better) category within a window of 5 adjacent grades. The effect is smaller for lower ratings within the NIG group (and eventually close to zero for the lowest ratings), and it is somewhere in the middle for the best ratings in the HIG group (about 3 percent change in probability). Similarly, OLS regressions indicate that a commensurate debt increase of 10 percent of GDP is associated with a decline in rating of almost $1 / 2$ of a notch for the middle rating range, which declines for lower ratings (again to gets close to zero for the lowest ratings) is again somewhere in the middle (about $1 / 4$ of a notch) for the highest rating grades.

The results in this paper would suggest that, on the basis of ratings as of May 282019 , emerging economies in the lower half of the investment grade range (LIG)-like Chile, Colombia, Mexico, Peru, and Russia-would experience similar effects (in terms of impact of debt on ratings) as advanced economies such as Italy, Portugal, and Spain, as they all belong to the same rating group. Countries like Bolivia, Dominican Republic, Guatemala, and Paraguay would experience an effect of debt on rating similar to Greece, all belonging to the non-investment grade (NIG) group as of May 28, 2019; and such an effect would be smaller than the one in the LIG group above.

The main findings of the public debt-credit ratings relationship investigated in this study are robust to alternative dependent variables, gross versus net debt definitions, and empirical specifications. 


\section{Annex I. Dominance Analysis}

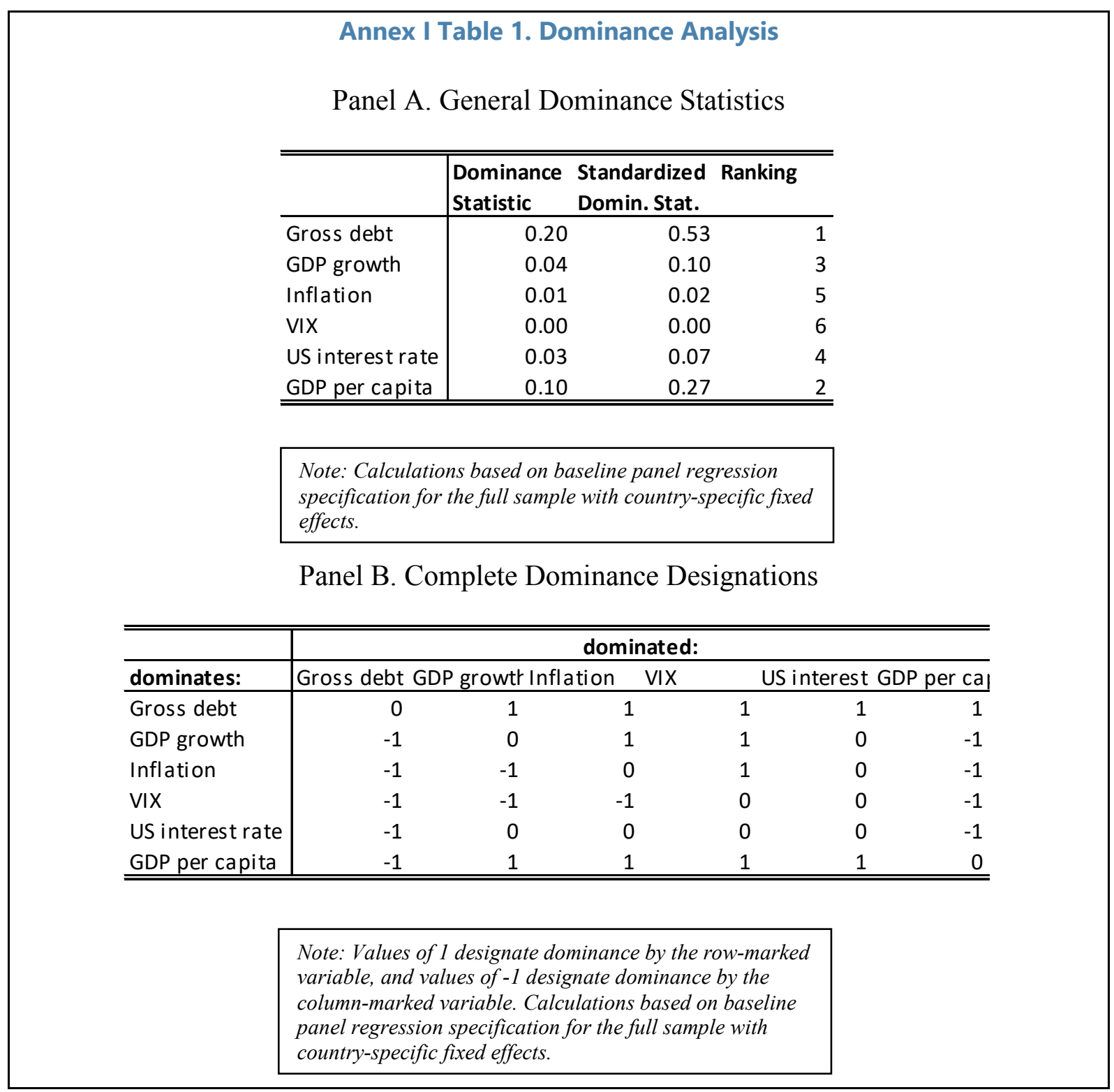




\section{Annex II. Debt-Ratings Relationship Across Regions}

\begin{tabular}{|l|cc|}
\hline \multicolumn{2}{|c|}{ Annex II Table 1. } \\
\hline \hline Region & $\begin{array}{c}\text { Coeff. Estimate } \\
\text { (separate } \\
\text { subsamples) }\end{array}$ \\
\hline Advanced Economies & Average rating & -0.06 \\
Emerging Europe & 19 & -0.06 \\
CIS & 14 & -0.01 \\
Emerging Asia & 11 & -0.04 \\
LAC & 14 & -0.05 \\
MENA & 12 & -0.04 \\
SSA & 14 & -0.01 \\
\hline \hline
\end{tabular}

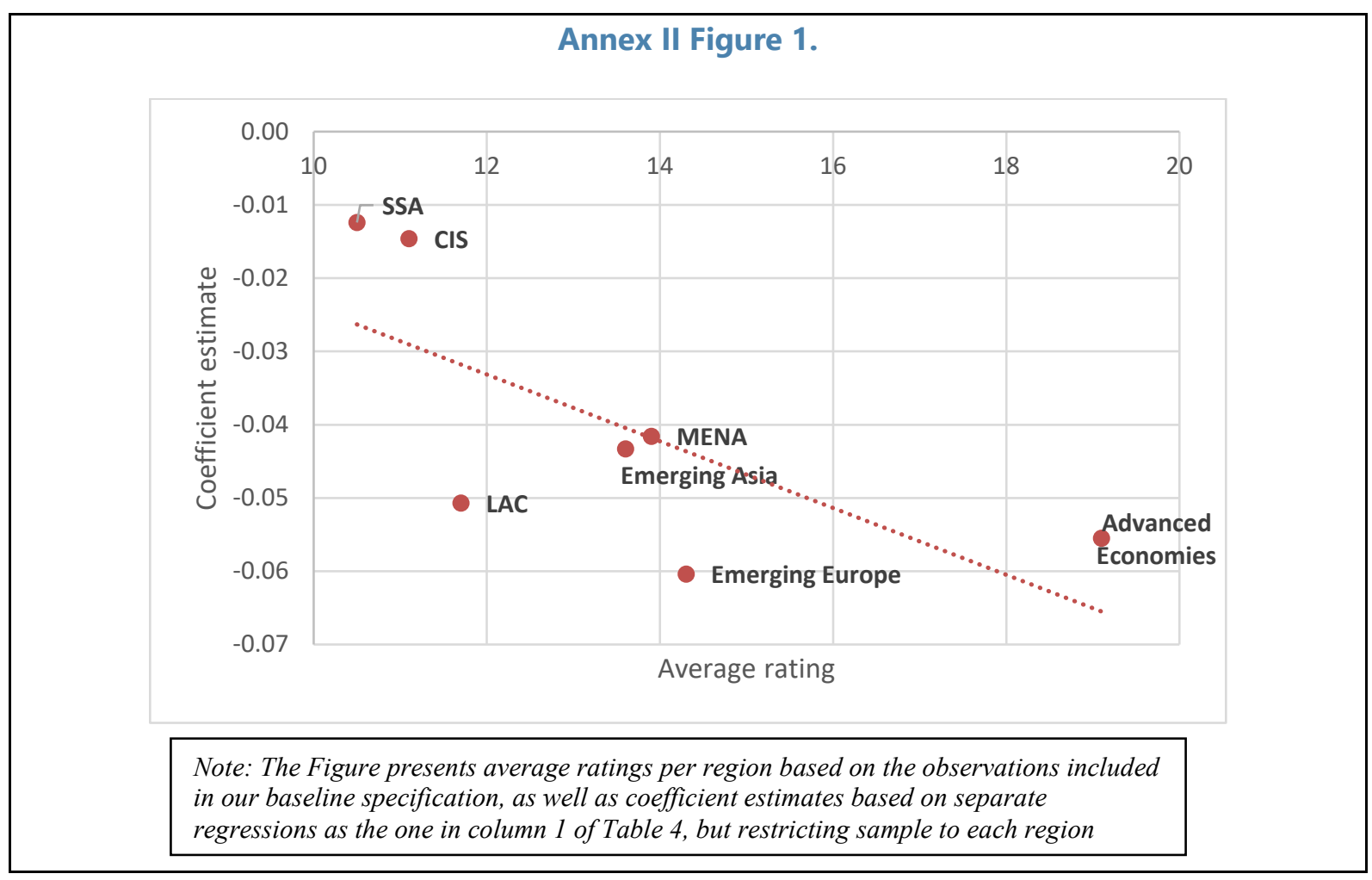

CInternational Monetary Fund. Not for Redistribution 


\section{References}

Afonso, A., P. Gomes, and Ph. Rother (2011), "Short- and Long-Run Determinants of Sovereign Debt Credit Ratings", International Journal of Finance and Economics, 16, 1-15.

Afonso, A. (2003), "Understanding the Determinants of Sovereign Debt Ratings: Evidence for the Two Leading Agencies", Journal of Economics and Finance, 27, 56-74.

Bissoondoyal-Bheenick (2005), "An Analysis of the Determinants of Sovereign Ratings", Global Finance Journal, 15, 251-280.

Boumparis, P., C. Milas, and Th. Panagiotidis (2015), "Has the Crisis Affected the Behavior of the Rating Agencies? Panel Evidence from the Eurozone", Economics Letters, 136, 118124.

Brůha, J., M. Karber, B. Pierluigi, and R. Setzer (2017), "Understanding Sovereign Rating Movements in Euro Area Countries", ECB Working Paper Series No 2011.

Budescu, D.V. (1993), "Dominance Analysis: A New Approach to the Problem of Relative Importance of Predictors in Multiple Regression”, Psychological Bulletin, 114, 542-551.

Cantor, R., and F. Packer (1996), "Determinants and Impact of Sovereign Credit Rating", Federal Reserve Bank of New York Economic Policy Review, October 1996, 37-54.

Ding, X. and M. Hadzi-Vaskov, 2017, "Composition of Trade in Latin America and the Caribbean,” IMF Working Paper No. 17/42 (Washington: International Monetary Fund).

Gaillard (2014), "What Is the Value of Sovereign Ratings?”, German Economic Review, 15, 208-224.

Grömping, U. (2007), "Estimators of Relative Importance in Linear Regression Based on Variance Decomposition, The American Statistician, 61, 139-147.

Gruber, J. W. and S.B. Kamin, 2012, "Fiscal Positions and Government Bond Yields in OECD Countries", Journal of Money, Credit, and Banking, Vol. 44 (8).

Hadzi-Vaskov, M. and L. A. Ricci, forthcoming, "Does Gross or Net Debt Matter More for Emerging Market Spreads?”, Journal of Money, Credit, and Banking.

IMF (2014), Government Finance Statistics Manual 2014, Washington, DC.

Luchman, J. N (2014), "Relative Importance Analysis with Multicategory Dependent Variables: An Extension and Review of Best Practices", Organizational Research Methods, $17,452-471$.

Mora, N. (2006), “Sovereign Credit Ratings: Guilty Beyond Reasonable Doubt?”, Journal of Banking and Finance, 30, 2041-2062. 